Deep Sea Research Part II:

Topical Studies in Oceanography

2001; 48(14-15) : 2979-3021

http://dx.doi.org/10.1016/S0967-0645(01)00030-3

(C) 2001 Elsevier Science Ltd
Archimer http://www.ifremer.fr/docelec/ Archive Institutionnelle de l'Ifremer

\title{
Physical structures, advection and mixing in the region of Goban spur
}

\author{
John M. Huthnance ${ }^{*,}$, Henrique Coelho ${ }^{b}$, Colin R. Griffiths ${ }^{1,, c}$, Philip J. Knight ${ }^{a}$, Andrew P. Rees $^{c}$, \\ Bablu Sinha $^{c}$, Annick Vangriesheim ${ }^{d}$, Martin White ${ }^{e}$ and Paul G. Chatwin ${ }^{2, f}$
}

\author{
${ }^{a}$ Proudman Oceanographic Laboratory, Bidston Observatory, Bidston Hill, via Prenton, CH43 7RA, UK \\ ${ }^{b}$ Department of Mechanical Engineering, Instituto Superior Técnico, Avenida Rovisco Pais 1, 1096 Lisboa Codex, \\ Portugal \\ ${ }^{c}$ Plymouth Marine Laboratory, Prospect Place, West Hoe, Plymouth PL1 3DH, UK \\ ${ }^{d}$ Département Environnement Profond, IFREMER, Centre de Brest, B.P. 70, F-29280 Plouzané, France \\ e Department of Oceanography, Martin Ryan Marine Science Institute, University College Galway, Ireland \\ ${ }^{f}$ Institute of Marine Studies, University of Plymouth, Drake Circus, Plymouth PL4 8AA, UK \\ *: Corresponding author : jmh@pol.ac.uk
}

\begin{abstract}
The physical context for ocean margin exchange at Goban Spur is described. Observations adjacent to, prior to and during the Ocean Margin EXchange (OMEX) project of 1993-1996 are used. They include currents measured on moorings, drogued-buoy tracks; temperature and other data from CTD profiles, especially as indicators of vertical mixing; evidence from models, particularly for turbulence causing vertical mixing. These data are combined in estimates of (seasonally dependent) mean flow, tidal currents, other current variability, exchange and mixing over the main cross-slope section studied in OMEX and in nearby and contrasted locations (aided by the use of earlier and adjacent measurements). Causative physical processes are discussed: potentially northward flow along the continental slope, effects of Goban Spur topography, eddies, wind-driven transport, cascading, tides, fronts, internal tides, internal waves, surface waves. Among these, there is evidence that
\end{abstract}

- the along-slope flow, typically $\mathrm{O}\left(0.05 \mathrm{~m} \mathrm{~s}^{-1}\right)$, is reduced or even reversed in spring, is generally weaker than at some other margin sectors owing to the non-meridional alignment and indentations in the Celtic Sea slope, and may sometimes overshoot rather than follow the depth contours around Goban Spur;

- tidal currents are $O\left(0.2 \mathrm{~m} \mathrm{~s}^{-1}\right)$ on the adjacent shelf but $\mathrm{O}\left(0.1 \mathrm{~m} \mathrm{~s}^{-1}\right)$ or less over most of Goban Spur; they increase to the southeast;

- other (wind- and eddy-forced) contributions to the currents are typically $O\left(0.1 \mathrm{~m} \mathrm{~s}^{-1}\right)$ or less, except on the shelf, and decrease with depth;

- wind-, tide- and wave-forced currents are probably the most consistent agents of cross-slope exchange $\mathrm{O}\left(1 \mathrm{~m}^{2} \mathrm{~s}^{-1}\right)$, with topographic effects being important locally (canyons, spurs);

- stratification starts intermittently until early June, becomes shallower through June and deepens by September. In 1995, one storm on 5-8 September roughly doubled the upper mixed-layer depth to $>40 \mathrm{~m}$ and reinstated maximal primary production in the upper mixed layer;

- vertical mixing is intermittent, dominated by surface inputs (wind and waves); towards the southeast, internal waves of tidal origin are increasingly important for mixing across the thermocline;

- in the context of nutrient provision for primary production in the upper mixed layer, diffusion through the summer thermocline appears to be small unless internal waves strongly increase mixing. 


\section{Introduction}

There is current interest in enhanced productivity (possibly fuelled by oceanic nutrients) in coastal seas, transfer of dissolved and particulate matter from there to the ocean, shelf-sea and coastal responses to changes in climate, sea level and human activities. To study these topics, it is necessary to quantify fluxes across the ocean margin, fundamental to evaluating budgets of carbon, nutrients and trace elements between the continent, coastal zone and ocean. In turn, there is a need to assess the basic processes that determine the quantities, transformation and fate of material transported between the shelf and ocean, and to develop prognostic models for exchanges. The continental slope and shelf break also have their own distinct interest; enhanced and special processes play a major role in controlling interchanges between the shelf and ocean. Continental slopes may possibly be significant in whole-ocean diapycnal mixing (Garrett et al., 1993 ) in view of recent reduced estimates ( 1 to $2 \times 10^{-5} \mathrm{~m}^{2} \mathrm{~s}^{-1}$ ) of diapycnal mixing in the deep ocean interior (Toole et al., 1994).

Overall objectives in the Ocean Margin EXchange (OMEX) project are to measure and to model exchange processes at contrasted European ocean margins as a basis for the development of global models to predict the impact of environmental changes on the oceanic system, and more specifically on the coastal zone. The first phase of OMEX (1993-1996) focused on Goban Spur (south-west of the British Isles, Fig. 1). Here the continental shelf is very broad and vertical mixing of nutrient-rich deep ocean water with surface water induces enhanced primary production. This is against the background of several experiments in varied locations: e.g., the Shelf Edge Exchange Processes (SEEP) study off the eastern USA (Middle Atlantic Bight; Walsh et al., 1988 et seq.; Biscaye et al., 1994 et seq.), the Coastal Transition Zone Experiment off western USA (Brink and Cowles, 1991 et seq.) and the UK Land-Ocean Interaction Study (LOIS) Shelf Edge Study west of Scotland (measurements during 1995-1996). Measurements are wanted in a variety of locations where the various processes are individually well-developed to test their representation by models.

\subsection{OMEX location}

Goban Spur is "downstream" (in the sense of a north-westward along-slope current) from the energetic Celtic Sea shelf and upper slope. The reduced energy in currents there raises the possibility of deposition of suspended material from the Celtic Sea margin "upstream", and of successful use of sediment traps. The bathymetry is well known, from intensive surveying including multi-beam echo sounding, and is held digitally at the British Oceanographic Data Centre (IOC et al., 1997).

\subsection{Purpose and outline of paper}

The aim here is to describe the physics context over Goban Spur, as it affects the transport (advection, dispersion, mixing) of dissolved and particulate constituents taking part in biogeochemical cycles in the water. Physical processes control the larger-scale reversible advection and irreversible small-scale mixing of water and its constituents, and so underlie water characteristics and fluxes. The importance of physical scales is emphasised by Tett and Edwards (1984). For biological growth of rate $\mu$ and horizontal mixing represented by a diffusivity $\mathrm{K}_{\mathrm{H}}$, only patches of scale exceeding $\pi\left(\mathrm{K}_{\mathrm{H}} / \mu\right)^{1 / 2}$ survive; mixing smears out smaller patches in times less than $1 / \mu$. Continued production in illuminated surface layers depends on maintaining a supply of nutrients, usually by mixing from below or lateral transport. In OMEX over Goban Spur, lateral transports have been inferred as important in budgeting organic carbon transfers in the cross-slope section (McCave et al., 2000).

The following sections discuss in turn:

- hydrography and the physical process background thereto, as already known; 
- investigations made during OMEX and their results: current measurements on moorings means, seasonal, tidal and other variabilities; drogued buoys; CTD profiles; models and observations of vertical and lateral mixings;

- synthesis and discussion - processes and their contributions to fluxes (advective and diffusive);

- conclusions.

Table 1 shows notation used, with a priori values appropriate to the area of Goban Spur.

\section{Hydrographic and physical process background}

South-west of Britain, the Celtic Sea occupies a broad continental shelf (Fig. 1) from Brittany near $48^{\circ} \mathrm{N} 5^{\circ} \mathrm{W}$ to Ireland near $51^{\circ} \mathrm{N} 10^{\circ} \mathrm{W}$. Bordering this shelf, the continental slope is steep (typically 0.05 or steeper over the top $2000 \mathrm{~m}$ ) and heavily indented with canyons as it trends north-west to Goban Spur near $49^{\circ} \mathrm{N} 11^{\circ} \mathrm{W}$. Here the $200-\mathrm{m}$ contour trends north, but the continental slope becomes less steep (typically 0.03 or less) with few canyons. Goban Spur itself has an extensive $(\sim 80 \mathrm{~km})$ plateau in $900-1500-\mathrm{m}$ depth; with Porcupine Bank $\left(51^{\circ}-54^{\circ} \mathrm{N}, 13^{\circ}-\right.$ $\left.15^{\circ} \mathrm{W}\right)$ it semi-encloses Porcupine Sea Bight.

The Eastern North Atlantic Water (ENAW) of the adjacent ocean (Pollard et al., 1996) lies above a salinity maximum of about 35.6 at 900-1000-m depth, the remaining signal of Mediterranean water which at this latitude $\left(49^{\circ} \mathrm{N}\right)$ shows a salinity excess less than 0.1 ; OMEX measurements also suggest that it is confined close to the slope. Above this, salinities (35.5$35.55)$ tend to decrease to the north and to the west, but also to 35.4 or less onto the shelf to the east (e.g., Fuglister, 1960; Levitus et al., 1994; Lozier et al., 1995). Thus along-slope flow from the south-east is associated with higher salinities over the upper slope. Below the Mediterranean maximum, salinities decrease quite rapidly from about 35.5 at $1200 \mathrm{~m}$ to about 35.1 at $1500 \mathrm{~m}$ and a minimum 34.9-35.0 with associated oxygen maximum at 1900-2000 $\mathrm{m}$ (Labrador Sea Water, e.g., Bersch, 1995). Below this again, salinity increases to a maximum of about 34.95 at about $2500 \mathrm{~m}$ in North East Atlantic Deep Water (NEADW). Tsuchiya et al. (1992) consider that NEADW is a mixture of Mediterranean Outflow Water (MOW) and North West Atlantic Bottom Water (NWABW) with rather little (salinating) input from Iceland-Scotland Overflow Water (ISOW). However, van Aken (2000) finds that ISOW is necessary to account for biogeochemical values (e.g., nitrate). Finally, salinity decreases downwards to less than 34.92 in Lower Deep Water (LDW) with high Antarctic Bottom Water content, high salinity and low oxygen due to ageing (van Aken and Becker, 1996). The LDW is believed to circulate cyclonically around Goban Spur, Porcupine Bank and the entrance to Rockall Trough (Arhan et al., 1994; van Aken and Becker, 1996). More discussion can be found in McCave et al. (2000), see their Fig. 2, and in Hydes et al. (2000) with regard to the nutrients in these waters.

Temperatures (like salinities) also decrease to the north and west (Levitus and Boyer, 1994). Against the slope near $49^{\circ} \mathrm{N}$ winter values are $10-11^{\circ} \mathrm{C}$ down to about $700 \mathrm{~m}$, about $9^{\circ} \mathrm{C}$ at $900 \mathrm{~m}$ decreasing steadily to below $4^{\circ} \mathrm{C}$ at $2000 \mathrm{~m}$. In summer, this is capped by a seasonal thermocline in the top $100 \mathrm{~m}$ or so (the depth is specifically studied in the following, and is also subject to displacement by tens of metres by internal waves). Surface temperatures reach about $16^{\circ} \mathrm{C}$ (up to $19^{\circ} \mathrm{C}$ was recorded in OMEX at the end of the exceptionally hot summer of 1995 ). Temperature dominates salinity as a contribution to density in this context of seasonal stratification.

Fronts or sharp changes of temperature occur near the Celtic Sea shelf break. Associated local eddies of scale $20-45 \mathrm{~km}$ drive heat fluxes estimated as $\sim 0.006^{\circ} \mathrm{C} \mathrm{m} \mathrm{s}^{-1}$ over the vertical extent of the fronts (Pingree, 1979). This value is equivalent to an exchange velocity $\mathrm{u}=$ $\alpha^{\prime}\left(\mathrm{g}^{\prime} \mathrm{h}^{\prime}\right)^{1 / 2}=3.5 \mathrm{~mm} \mathrm{~s}^{-1}$ (following Pingree, 1979, but with $\mathrm{g}^{\prime}=0.014 \mathrm{~m} \mathrm{~s}^{-2}, \mathrm{~h}^{\prime}=30 \mathrm{~m}$; see Table 
1) or to a lateral diffusivity $K_{H}=100 \mathrm{~m}^{2} \mathrm{~s}^{-1}$ (equating flux estimates $\mathrm{u} \Delta \mathrm{T}=\mathrm{K}_{\mathrm{H}} \Delta \mathrm{T} / \mathrm{L}$ for a crossfrontal scale $\mathrm{L}=30 \mathrm{~km}, \Delta \mathrm{T}$ denoting the temperature difference across the front).

Internal tides are believed to cause these fronts by local internal mixing. The internal tides themselves are formed when tidal flow across the steep continental slope induces vertical displacements and associated pressure fields. They are very sensitive to the form of topography and stratification, and propagate slowly $\left(<1 \mathrm{~m} \mathrm{~s}^{-1}\right)$; hence they are affected by strong advective tidal currents (Pingree et al., 1982). At the Celtic Sea shelf edge, large tidal currents $\left(>0.5 \mathrm{~m} \mathrm{~s}^{-1}\right)$ cause large internal tides (vertical displacements up to $150 \mathrm{~m}$; Pingree and New, 1989). Sun-glint images have shown that these waves can propagate on-shelf as a coherent sequence of plane waves, extending hundreds of kilometres laterally and over as many as seven tidal periods (Pingree and New, 1995). However, the waves often steepen and divide into groups of higherfrequency waves including solitons (e.g., Pingree et al., 1983; Pingree and New, 1995). These non-linearities favour tidally averaged transports of water in the upper layer $\mathrm{O}\left(1 \mathrm{~m}^{2} \mathrm{~s}^{-1}\right)$ (based on soliton amplitude $=30 \mathrm{~m}$ and combined length of solitons $=2 \mathrm{~km}$ per tide; Pingree and New, 1995).In general there will be a compensating return flow at other depths in the water column; this is an exchange transport rather than a depth-integrated transport. Strong shear in the steep waves also favours turbulence, internal mixing and enhanced chlorophyll near the shelf break (Pingree, 1988; New, 1988: Dickson et al., 1980; Pingree et al., 1982; New and Pingree, 1990; Pingree and New, 1995). Such mixing in association with internal tides can thicken the summer thermocline internally and cool the sea surface by $1-2^{\circ} \mathrm{C}$ in an irregular band $50-100-\mathrm{km}$ wide over the Celtic Sea shelf break (e.g., Pingree, 1984). The phenomenon is most intense where cross-slope tidal currents are strongest, in the southern Celtic Sea. Here Pingree (1979) shows a section with the thermocline $\left(12^{\circ}\right.$ to $\left.18^{\circ} \mathrm{C}\right)$ spanning the upper $80 \mathrm{~m}$, contrasting with just 20-to30-m depth on the adjacent shelf. The phenomenon becomes weaker and more intermittent towards Goban Spur. Internal tide models include a 2-D idealised cross-section with continuous stratification (New, 1988), which shows the concentration of motion and potential mixing along characteristics meeting the shelf break; Serpette and Mazé (1989) have two horizontal dimensions with 2-layer stratification.

Heat loss (often aided by strong winds) and hence convection give winter mixing to depths $\mathrm{O}(500 \mathrm{~m})$ increasing northwards; mixing is as deep as $1000 \mathrm{~m}$ in Rockall Trough. This winter cooling, by lowering the temperature for given salinity, increases the salinity for given (low) temperature and so is thought to contribute to the apparently enhanced ENAW salinities (Pollard et al., 1996). The Celtic Sea is normally well mixed in winter; temperature and salinity tend to compensate in their effect on density (the water is cooler and fresher as it shoals towards land). This compensation will not normally be exact under variable cooling, mixing and fresh-water inputs; indeed, James (1980) shows a nearer-shore example with salinity stratification (cold fresh on top) in late winter.

Mean currents (specifically studied in the followingsections) tend to be along the slope with speeds $\sim 0.02$ (deep) to $\sim 0.1 \mathrm{~m} \mathrm{~s}^{-1}$ at the shelf break (Pingree and Le Cann, 1989). This is part of a northward flow along the continental slope around the west of Britain (Pingree and Le Cann, 1989; Huthnance, 1986). Although only $0.1 \mathrm{~m} \mathrm{~s}^{-1}$ or weaker over Goban Spur, it is possibly important for advecting material from the tidally energetic slope area bordering the Celtic Sea to the south east. Moreover, there may be associated cross-slope flow and exchange (Huthnance, 1984). Oceanic baroclinic flow, associated with meridional density gradients that form a likely forcing for the along-slope flow (Pingree and Le Cann, 1989), may come over the slope. A corresponding "downwelling" (off-shelf) bottom Ekman transport $\tau /(\rho f)$ is also expected.Recent models by Mellor and Wang (1996) and Chapman and Lentz (1997) suggest that on long time-scales the cross-slope flows may adjust the density field, so that geostrophic shear in the along-slope flow reduces the bottom stress and Ekman transport almost to zero. However, these models do not have cross-slope diffusion nor persistent forcing. Down-slope 
residual currents as strong as $0.15 \mathrm{~m} \mathrm{~s}^{-1}$ have been recorded on the upper slope near La Chapelle Bank where internal tide generation is strongest (Pingree and Le Cann, 1989).

Current variance has several causes now discussed.

Eddies (and associated cross-slope flow) occur, related to the along-slope current. Drogued buoys provided evidence of an anticyclonic Porcupine eddy off north-west Ireland (Booth, 1988) and satellite images suggested an eddy pair at the end of a filament originating near the slope. Pingree (1993) showed an anticyclonic eddy in the Porcupine Seabight persisting for about six months. Anti-cyclonic slope-water eddies in the Bay of Biscay (Pingree and Le Cann, 1992a,b) form in winter if the warm flow along northern Spain is strong (Pingree, 1994). Over Goban Spur (1000-2000-m water depth) a remote-sensed sequence of infra-red images during OMEX shows a cyclonic eddy $\sim 100-\mathrm{km}$ diameter persisting for a period of at least 8 days (Miller et al., 1996).A numerical model has shown eddies $\sim 100-\mathrm{km}$ diameter set up behind submarine spurs projecting from capes, in flow alongside the Japanese shelf (Awaji et al., 1991).

Wind-driven offshore transport $\tau /(\rho f)$ of upper waters is expected to force "upwelling" of deeper ocean waters to the shelf, to maintain continuity in the cross-shelf section. Around western Europe, this is most prominent off western Iberia. There is evidence of occasional upwelling west of Scotland and Ireland (Booth and Ellett, 1983; Dickson and McCave, 1986); preconditioning by cessation of the downwelling-favourable slope current may help. Over Goban Spur, upwelling should be during intermittent northerly winds.

Pingree and Le Cann (1989) show results from a 2-D model for the response to steady wind stress in varied directions. For sections across the shelf, their model suggests relations for a transport Q (Sv) on the shelf in a northwestward sense parallel to the shelf edge:

$$
\begin{array}{ll}
\mathrm{Q}=8.1 \tau \cos \left(\theta-142^{\circ}\right), & \mathrm{Q}=5.4 \tau \cos \left(\theta-152^{\circ}\right) \\
\text { south-west of Ireland } & \text { Armorican Shelf }
\end{array}
$$

respectively, where $\theta$ is the direction the wind is blowing from, $\tau$ is wind stress $\left(\mathrm{N} \mathrm{m}^{-2}\right)$. For a typical wind stress $\tau \sim 0.1 \mathrm{~N} \mathrm{~m}^{-2}$ these values are comparable with along-slope transports, and suggest that wind-forced flow on this broad shelf may be significant in cross-slope transports. In Fig. 2 of Pingree and Le Cann (1989) the north-westerly wind stress $0.16 \mathrm{~N} \mathrm{~m}^{-2}$ forces more than 1.3 Sv into the Celtic Sea (allowing for the extra inflow from the Irish Sea and Channel) but only $0.83 \mathrm{~Sv}$ outflow to the Armorican Shelf; $0.5 \mathrm{~Sv}$ appears to be exported across the shelf edge. The same authors also show a slope current resulting from pressure-gradient "JEBAR" forcing associated with meridional density gradients in the adjacent Atlantic ocean. Seasonal variations in the atmospheric forcing and in the adjacent Atlantic density field will result in changes in the along-slope flow.

More generally, strong but variable wind forcing will drive along- and cross-slope flows. A natural response in horizontally uniform conditions is as rotary anticyclonic "inertial" currents (see Baines, 1986). For barotropic oscillations over the shelf and slope, this is modified by the topography to a continental shelf wave of maximum frequency; the currents are sub-inertial but still rotary, anticyclonic and strongest near the shelf break (Huthnance, 1981). The initial velocity $\sim \tau \mathrm{t} / \mathrm{\rho h}$ (for wind stress $\tau$ of duration $\mathrm{t}$ ) is greater in shallow water (depth $\mathrm{h}$ ) or if seasonal stratification reduces the effective depth $h$. Short-period responses may easily cross the slope; winds of longer period $\left(>>\mathrm{f}^{-1}\right)$ tend to force geostrophically constrained flow along the slope. Barotropic models describing such wind-forced flows are run operationally for the northwest European shelf to $12^{\circ} \mathrm{W}$ (Flather et al., 1991). Inertial waves and shear across the seasonal thermocline are important to downward mixing (Pollard et al., 1973; Largier, 1990).

Cascading is an irreversible exchange of oceanic and shelf waters. It occurs when shelf waters (are cooled to) become more dense than adjacent waters over the slope, and is sensitive to hydrographic conditions. Evidence of individual cascading events has been found over Rockall Bank (D.J. Ellett, personal communication), the Hebrides shelf and north-west of Ireland (Hill et al., 1998; Shapiro and Hill, 1997) and off the shelf of the Celtic Sea (Cooper and Vaux, 1949). 
Tides are enhanced by North Atlantic basin dimensions that correspond to near-resonance at semi-diurnal frequencies, and further by a nearly resonant $1 / 4$-wave across the wide Celtic Sea. Cross-slope transports to supply these tidal waters to the shelf are large, $\mathrm{O}\left(\sigma \mathrm{L}_{\mathrm{S}} \zeta\right) \sim 30 \mathrm{~m}^{2} \mathrm{~s}^{-1}$ over Goban Spur for semi-diurnal frequency $\sigma$, effective shelf width $L_{S} \sim 200 \mathrm{~km}$ and tidal elevation $\zeta$ $\sim 1 \mathrm{~m}$. However, most of the transport is returned each tidal period and shear dispersion may be the main process of lasting exchange. Prandle (1984) found an effective dispersion coefficient $t_{D} u|\mathbf{u}|$ where $t_{D} \sim 10^{3}$ s matched a tidal-average model to observed dispersion on the north-west European shelf. Barotropic tidal models are well-established: Flather (1981) covers the northeast Atlantic; Pingree et al. (1982) cover the Celtic Sea shelf in more detail.

Internal waves occur in the ocean with a wide spectrum of frequencies. The shelf edge is one effective source, via internal tides. Lee waves may form in longer-period flow along an uneven slope (Thorpe, 1992), radiating energy preferentially up-slope, as found in the Celtic Sea context (Holt and Thorpe, 1997). If the continental slope is characteristic for internal waves, bottom currents may be intensified; there appears to be evidence of this at 400-500-m on the Celtic Sea slope (Pingree and Le Cann, 1989) where $0.15 \mathrm{~m} \mathrm{~s}^{-1}$ down-slope residual currents are also found. Bottom-intensified currents encourage the movement of sediments. Thorpe and White (1988) found evidence that the off-shelf nepheloid layer was most extensive where this occurred (for $\mathrm{M}_{2}$ frequency) on the west side of Porcupine Bank; Dickson and McCave (1986) found evidence of nepheloid layers when this condition occurred higher on the western slope of Porcupine Bank. Various effects of enhancement, distortion, reflection, rectification and breaking, especially near the bottom, facilitate energy input to mixing (e.g., Thorpe, 1987a; Thorpe et al., 1990; Taylor, 1993).

Current variance (incorporating any eddy motions, wind-forced flow, internal waves), tides and seasonality are newly evaluated here, as are contributions to lateral exchange and vertical mixing.

Surface waves contribute to turbulence and mixing through near-surface shear and breaking and (in the case of very long waves on the shelf) through currents at the bed.

Flow across depth contours may be helped by friction and by shelf-edge bends of smallenough scale $\mathrm{L}_{\mathrm{T}}$, via (i) stratification decoupling the flow from the topography if $\mathrm{L}_{\mathrm{T}}<$ internal deformation radius (ii) inertia if $\mathrm{L}_{\mathrm{T}}<|\mathbf{u}| / \mathrm{f}$.

\section{Methods and results}

We consider the area close to or over the continental slope bounded by $47.5^{\circ}$ to $55^{\circ} \mathrm{N}, 7^{\circ}$ to $16^{\circ} \mathrm{W}$, so as to include Goban Spur and the adjacent slope region to the north and to the south east as far as La Chapelle Bank, to provide supporting data and also some contrast (notably, increasing tidal energy to the south east).

\subsection{Moored current data}

Measurements over one month or longer have been considered, including all OMEX moorings in the area but also the many other sources (a majority) listed in Table 2 and shown in Fig. 1. Many of the data listed were analysed in Pingree and Le Cann $(1989,1990)$.

Although the OMEX moorings themselves are a minority of those considered, they form the entirety actually over Goban Spur, the OMEX location chosen for reasons already mentioned. Moreover, they are the only records in the area contemporary with the other measurements, and also include the longest records in the set.

The following current statistics were calculated:

month by month:

- mean components to east and north; 
- stability factor $|<\mathbf{u}>| /<|\mathbf{u}|>(<. .>$ denotes time-averaging over the records; in this case $\mathbf{u}$ is after subtracting tides and higher frequencies);

per record:

- tidal constituents by standard least-squares analysis including semi-diurnal $\left(\mathrm{M}_{2}, \mathrm{~S}_{2}, \mathrm{~N}_{2}\right)$ and diurnal $\left(\mathrm{K}_{1}, \mathrm{O}_{1}, \mathrm{P}_{1}\right)$ ellipse axes, orientation, polarity and phase;

- variance (representing other contributions to total energy and most relevant here as an indicator of exchange flows) after removal of analysed tide and record mean, as maximum resolved component, direction thereof and minimum resolved component (intended as indicators of "along" and "across" the slope respectively). This is spectrally analysed in section 3.5.

\subsection{Drogued buoys}

Drogued buoys (as opposed the current moorings) give a quasi-Lagrangian view of the flow and its continuity for transports (as discussed in section 4.1).

A drogue, designed and constructed by Plymouth Marine Laboratory, was attached to an Argos buoy for a depth of $40 \mathrm{~m}$ and deployed on day 308,1995 at $49.91^{\circ} \mathrm{N}, 9.66^{\circ} \mathrm{W}$ over the outer Celtic Sea shelf on RRS Charles Darwin cruise CD97, 1995 (report: PML, 1995). Pingree et al. (1999) give results as follows. The drogue tracked northwards to near $51^{\circ} \mathrm{N}, 9.5^{\circ} \mathrm{W}$ off southern Ireland (day 340), north-westwards and northwards along the upper slope off western Ireland (day 350, 1995 to day 5, 1996) and western Scotland (until day 20), northeastwards from off Lewis/Harris Islands and northern Scotland to north east of Shetland (day 80) as shown in Pingree et al. (1999), Figure 14. During the next 80 days it moved a relatively short distance east of Shetland. In the period from day 350, 1995 to day 20, 1996 of most sustained along-slope flow, it moved about $750 \mathrm{~km}$ along the slope, an average of $0.25 \mathrm{~m} \mathrm{~s}^{-1}$. The maximum 5-day average exceeded $0.4 \mathrm{~m} \mathrm{~s}^{-1}$ along the steep slope from $54^{\circ}$ to $57^{\circ} \mathrm{N}$ where the drogued-buoy path closely followed the 200-m depth contour. This path suggests a continuous along-slope flow poleward from Goban Spur during the winter 1995/96 of the deployment, a suggestion reinforced by current meter data analysis in section 3.3

Pingree et al. (1999) also report on-shelf movement of a drifting mooring from the Celtic Sea shelf break to the buoy deployment position during the previous 20 days. Previous drogued buoys (Pingree et al., 1999) have also shown relatively slow cyclonic flow within the Celtic Sea closer to the coast, and persistent ( $>100$ days) anticyclonic eddies in Porcupine Seabight.

\subsection{Mean currents (seasonal variation)}

Mean flows ("near surface" and "others" at each location) are illustrated for April and October in Fig. 2. A full seasonal cycle of monthly vectors for these locations west of Ireland is shown in White et al. (1997). The designation "near surface" is only used for the top current meter on any mooring, and then only if within the top one-third of the water column. Typically, the mean flow over the slope is stronger and more consistent in direction (along the slope "northwards") than over the adjacent shelf or the deeper ocean. There are several instances where the monthly mean is greater close to the bottom than further up the water column, as well as vice versa. Consistency within months is illustrated by a prevalence of stability factors $>50 \%$.

The mean flow is more consistently "northwards" in October than in April, when there are several locations with the uppermost flow reversed. In particular, mooring PML154n gave records over 502 days (Pingree et al., 1999). There, monthly-mean flows show a southward component in spring (March-May; sampled twice), a north to north-eastward direction in summer (June-August) and a varying north-westward character in autumn and winter (the flow at $50 \mathrm{~m}$ above bed is aligned more closely along the slope).

In order to obtain more consistent estimates of mean flows and seasonal variations, given that most of the contributing records are shorter than one year and are not contemporary, a representation as 


$$
\mathbf{u}(\mathrm{t})=\mathbf{m}+\mathbf{s} \mathrm{c}(\mathrm{t})
$$

was attempted. Here $\mathbf{u}$ is the set of two velocity components at all measurement locations; monthly mean values are used, indexed by $\mathrm{t}=1, \ldots, 12 ; \mathbf{m}, \mathbf{s}$ and $\mathrm{c}(\mathrm{t})$ are to be found as a leastsquares error approximation. Then $\mathbf{m}$ will represent the mean flow at each location, and $\mathrm{c}(\mathrm{t})$ is a common annual cycle with amplitude $\mathbf{s}$ at each location. Clearly locations with only one month's mean value are of no help in determining differences of $\mathrm{c}(\mathrm{t})$ between months; correspondingly, after $\mathrm{c}(\mathrm{t})$ is determined, there is indeterminacy between $\mathrm{m}_{\mathrm{i}}$ and $\mathrm{s}_{\mathrm{i}} \mathrm{c}(\mathrm{t})$ for the one month $\mathrm{t}$ when $\mathrm{u}_{\mathrm{i}}$ is known for such a location and component $i$. Therefore, without loss, just locations with two or more monthly mean values are involved in the analysis. The procedure is iterative, starting (arbitrarily) with all components of $\mathbf{s}$ equal to unity, solving for $\mathrm{c}(\mathrm{t}), \mathbf{m}$, then for new $\mathbf{s}$, again for $\mathrm{c}(\mathrm{t}), \mathbf{m}$ and so forth. Indeterminacy between amplitudes of $\mathbf{s}, \mathrm{c}(\mathrm{t})(\gamma \mathbf{s}, \mathrm{c} / \gamma$ is equally valid for any $\gamma$ ) is removed by constraining $\Sigma_{\mathrm{t}} \mathrm{c}^{2}=1$. In practice convergence was achieved after about 30 iterations.

Results in Fig. 3 show a mean flow $\mathbf{m}$ polewards along the slope, and seasonal variability $\mathbf{s}$ also primarily along the slope with opposite maxima in April and October, confirming a "September/October - March/April" (SOMA) effect (Pingree et al., 1999). Intriguingly, the seasonal signal $\mathbf{s}$ appears to reverse near $51.5^{\circ} \mathrm{N}$. To the south, including Goban Spur and the Celtic Sea as in Pingree et al. (1999), April flows are equatorward (i.e., the overall poleward flow is weakened or reversed) and October flows are more strongly poleward. This seasonal signal might have hindered the drogued buoy, had it been in spring not December. North of $51.5^{\circ} \mathrm{N}$, poleward flows are stronger in spring and weaker in autumn.

It should be cautioned that most of the records contributing to this seasonal analysis are shorter than one year and are not contemporary (Table 2), so that the inference of any seasonal trends is susceptible to bias and depends primarily on the large number of records used. Hence robustness of the analysis was checked by performing it again, restricted to the subset of series with three or more monthly values. The SOMA result is common to the complete and restricted analyses (Fig. 3c); the vectors $\mathbf{m}$ and $\mathbf{s}$ differ little where included in the restricted analysis (not shown).

\subsection{Tidal currents}

Semi-diurnal currents are dominant in the area. Their amplitudes are well-represented by the largest constituent $\mathrm{M}_{2}$. Thus results of the tidal analyses are illustrated by the map in Fig. 4 with major and minor tidal ellipse axes at near-surface and other current meters for $\mathrm{M}_{2}$; as the largest constituent, it is the most reliably determined in any record subject to incoherent contributions (particularly from internal tides in varying stratification). $\mathrm{S}_{2}$ and $\mathrm{N}_{2}$ amplitudes are typically $38 \%$ and $21 \%$ of $\mathrm{M}_{2}$, respectively (close to their ratio in the tide generating potential, i.e., spring-neap variations $\sim 40 \%$. $)$. $\mathrm{K}_{1}$ is typically the largest diurnal constituent, $\mathrm{O}\left(0.01 \mathrm{~m} \mathrm{~s}^{-1}\right)$ except around south-west Ireland and on Porcupine Bank where the stronger diurnal tidal currents have previously been noted and modelled (Pingree and Griffiths, 1984). Other tidal constituents are smaller.

The $\mathrm{M}_{2}$ (major axis) values show a strong decrease to the north-west from La Chapelle Bank towards Goban Spur [O $\left(0.4 \mathrm{~m} \mathrm{~s}^{-1}\right)$ to $\mathrm{O}\left(0.2 \mathrm{~m} \mathrm{~s}^{-1}\right)$ on the shelf] as previously observed and modelled by Pingree et al., (1982). Values (depth-averaged except for STABLE) also decrease down the slope, e.g.,

$$
\begin{array}{lrrrrrl} 
& 0.24 & 0.10 & 0.08 & 0.05 & 0.05 & \mathrm{~m} \mathrm{~s}^{-1} \\
\text { in water of depth } 142 & 879 & 996 & 1445 & 3651 & \mathrm{~m}
\end{array}
$$

close to the OMEX measurement section over Goban Spur (moorings PML150n, STABLE - near bed, PML154n, OMEX2, OMEX3; see Fig. 1, Fig. 4). Typical deep tidal currents are $0.05 \mathrm{~m} \mathrm{~s}^{-1}$.

Agreement with models (e.g., Kwong et al., 1997; Pingree et al., 1999) is good with respect to all barotropic tidal ellipse parameters, allowing confidence in using a tidal model to 
estimate depth-averaged tidal currents at other locations in the Goban Spur section. In these analysed coherent tides, Fig 4. shows only small-to-moderate internal tides as current variation with depth; $\mathrm{O}\left(0.05 \mathrm{~m} \mathrm{~s}^{-1}\right)$ rather than a proportion of the barotropic current.

\subsection{Other current variability}

Residual variance is illustrated in the same fashion as the $\mathrm{M}_{2}$ tide by the map in Fig. 5 with major and minor variance ellipse axes at near-surface and other current-meters. Values of rootmean-square currents are typically $0.1 \mathrm{~m} \mathrm{~s}^{-1}$ over the steep mid-slope, but $0.05 \mathrm{~m} \mathrm{~s}^{-1}$ at deeper locations including the sediment trap moorings OMEX2 and OMEX3 on Goban Spur, and $0.2 \mathrm{~m}$ $\mathrm{s}^{-1}$ on the adjacent Celtic Sea shelf. Fig. 6 shows a clear decrease of current variance (major + minor axes of residual variance ellipse) as either water depth or instrument depth increases (the latter relation is closer), contrasting with mean-flow behaviour. However, there is no clear trend of ellipticity with either water depth or instrument depth (not shown); closer alignment of currents with depth contours (and hence a narrower variance ellipse) might have been expected over the steep slope (intermediate water depths) or for instruments closer to the bottom.

Spectra for locations PML154n, PML150n (Pingree et al., 1999) all show energy peaks in the inertial-tidal bands (with relatively large 1/4-diurnal tides at location PML150n on the shelf), at $\sim 10$ days (PML150n; PML154n) and at $\sim 50$ days (PML154n). Fig. 7 shows the sum of spectra for all series in Table 2. This spectrum is "red" with relatively high low-frequency energy (although systematic treatment of "eddy" incoherent variability with periods greater than 30 days is inhibited by the varied record lengths), plus particular peaks at the inertial frequency $(\sim 0.063$ cycles per hour, attributable to the near-surface response to wind forcing) and multiples of the semi-diurnal tidal frequency ( $\sim 0.081$ cycles per hour). The latter indicate significant incoherent tidal energy, often associated with internal tides; typical root-mean-square amplitude is $0.03 \mathrm{~m} \mathrm{~s}^{-}$ ${ }^{1}$, fairly small relative to the coherent tides. The 2-D model response of Pingree and Le Cann (1989; Q $-\tau$ relations (1) above) is relevant to the longer-period parts of the spectrum, which surely include wind-forced contributions.

\subsection{Other current data}

Additional OMEX measurements (not directly comparable with the above) provide information near the sea bed. "Spot" values of near-bed current were obtained along the OMEX section across Goban Spur (Thomsen and van Weering, 1998). Although not corrected for stage of the tidal cycle or other time-varying factors, the spot values indicate the possibility of relatively strong currents exceeding $0.3 \mathrm{~m} \mathrm{~s}^{-1}$ over the plateau of Goban Spur near the OMEX 2 sediment-trap mooring site in $1445 \mathrm{~m}$. Measurements at $0.25,0.5,0.75$ and $1 \mathrm{~m}$ above bed in 1296-m water depth on the same section over a year (BOBO; see Thomsen and van Weering, 1998) showed maximum speeds to $0.15 \mathrm{~m} \mathrm{~s}^{-1}$. The "Sediment Transport and Boundary Layer Equipment" (STABLE) made high-frequency measurements of near-bed currents during 21-31 January 1994 in 879-m water depth. From these, bottom stresses have been derived (Chatwin, 1996), with maximum value $u_{*} \equiv(\text { stress } / \rho)^{1 / 2} \sim 13 \mathrm{~mm} \mathrm{~s}^{-1}$ but more typically $5 \mathrm{~mm} \mathrm{~s}^{-1}$ at the peak of the dominant tidal currents. By contrast, Pingree and Le Cann (1989) fitted a logarithmic profile to instantaneous near-bed currents in $540 \mathrm{~m}$ on the west flank of a canyon $\left(48^{\circ} 12.9^{\prime} \mathrm{N}\right.$, $9^{\circ} 15.7^{\prime} \mathrm{W}$, where tidal currents are stronger) to obtain $\mathrm{u}^{*}=18 \mathrm{~mm} \mathrm{~s}^{-1}$.

\subsection{Vertical mixing}

In order to determine the thermocline depth, minimising and estimating errors due to aliasing by internal tides and near-surface diurnal heating, repeated CTD stations spanning periods of a few hours to about two days were identified. In cases of doubt, mean depths were estimated for a particular temperature common to a sharp thermocline at the base of the mixed 
layer in all repeated profiles. This contrasts with averaging temperature at each depth, which can smooth out large gradients in a thermocline that moves during the period averaged.

Results are illustrated in Fig. 8. They show an uncertain start to the seasonal stratification during late April and early May (1994 cruises) with occasions both of weak stratification at rather variable depths $\mathrm{O}(40 \mathrm{~m})$ and of mixed conditions. In 1994 and other years stratification has been evident in April/May with the onset of a spring bloom (Garcia-Soto and Pingree, 1998; Rees et al., 1999 for spring 1994), the appearance of internal tides (e.g., Fig. 13 in Pingree and New, 1995) and in CTD measurements over a week's period. The evidence for June (mostly from one 1995 cruise) shows mixed-layer depths from 27 to $46 \mathrm{~m}$; one 1994 estimate is considerably deeper. Values for late June and early July (1993 cruises) are 17 to $37 \mathrm{~m}$. Although the inference of shoaling by about $10 \mathrm{~m}$ from June to July is uncertain because the data are from different years, it is supported by values 20 to $37 \mathrm{~m}$ in late August and early September 1995; i.e., shoaling by about $10 \mathrm{~m}$ took place at some time in 1995 also.

The 1995 data show a clear deepening between 4 September and 9 September, after which values are between 41 and $57 \mathrm{~m}$. Interesting exceptions are: $28 \pm 4 \mathrm{~m}$ on 8 September further west than the other stations around this time $\left(12.4^{\circ} \mathrm{W}\right.$ rather than $\left.9-10^{\circ} \mathrm{W}\right) ; 33 \pm 6 \mathrm{~m}$ on 13 September for the only on-shelf station around this time; $48 \pm 8$ and $80 \pm 11 \mathrm{~m}$ on 23-24 September (this latter, deeper thermocline is well developed for this particular time and location but for the other CTDs only the uppermost sharp thermocline has been plotted). Another clear change from 4 to 9 September occurs in the chlorophyll profiles. Until 4 September there are nice examples of a chlorophyll maximum at 40-45-m depth within the thickness of the thermocline and distinctly below the mixed layer where chlorophyll values are hardly elevated at all. From 9 September, chlorophyll profiles closely match those of temperature, i.e., values are highest in the surface mixed layer. These changes coincide with a storm (winds up to force 10 to 11) in the period 5-8 September (which caused RRS Discovery to seek shelter elsewhere).

Deepening of the mixed layer between early and late summer is also evident for 1993, from 17-37 m (June/July) to 46-58 m (late September); however, the date(s) of deepening were not observed.

There is little evidence in these data of any consistent relation between mixed-layer depth and location over the shelf, slope or deeper ocean. Four sets of profiles in 9-18 September 1995 just possibly suggest that after the storm the mixed-layer depth may have correlated with total water depth.

In principle, vertical diffusivity might be estimated from successive CTD profiles by inverting the equation for vertical structure of a conservative constituent $\mathrm{C}$ :

$$
\mathrm{dC} / \mathrm{dt}=\partial / \partial \mathrm{z}\left(\mathrm{K}_{\mathrm{s}} \partial \mathrm{C} / \partial \mathrm{z}\right) \text {. }
$$

However, it is clear from the data that individual storms can cause (in a few days) as much change to profiles as may otherwise occur through several summer months. Therefore any value of diffusivity inferred from the available data will depend strongly on whether a strong mixing event occurred. Typically, the value would also be derived from profiles separated by a relatively long time (months) and would not represent either the few stronger mixing events included or the relatively weak mixing generally present.

Instead, a modelling approach to estimate effective vertical diffusivity has been tried.

\subsection{Estimation of oceanic vertical mixing from a one dimensional eddy kinetic energy model.}

Atmospheric data and sea surface temperature from the $\mathrm{K} 1$ buoy at $48.7^{\circ} \mathrm{N}, 12.4^{\circ} \mathrm{W}$ over Goban Spur were made available by the UK Meteorological Office via the British Oceanographic Data Centre (BODC). Data were for the period 1 June 1993 to 30 June 1995. These data include near-surface air temperature and humidity, wind speed, wind direction, barometric pressure, dew-point temperature, wet bulb temperature, Sea Surface Temperature (SST) and measured wave height and period. All data are available with a sampling period of 3 
hours (1 hour from September 1994). Wind stress, latent heat flux and sensible heat flux were computed from observational atmospheric data using Large and Pond (1981, 1982); bulk formulae and net infrared radiation were deduced from the Kondratyev (1969) formulae. As no radiometer data were available, climatological insolation from Esbensen and Kushnir (1981) was used.

Previous work, simulating the diurnal cycle of temperature observed during the Long Term Upper Ocean Study (LOTUS) in the Sargasso Sea and the seasonal cycle of temperature off the Iberian coast, showed similar results produced by two different models, based on the Gaspar et al. (1990) one-equation turbulence closure and on the quasi-equilibrium version of the level 2.5 Mellor and Yamada closure scheme (Galperin et al., 1988) respectively. For simplicity, therefore, the one-equation closure scheme was adopted in this work. The one-dimensional (no Ekman pumping) forms of the balance equations for temperature, salt and momentum, using the Gaspar et al. (1990) notation, are

$$
\begin{gathered}
\frac{\partial \bar{T}}{\partial t}=\frac{F_{s o l}}{\rho_{o} C_{p}} \frac{\partial I}{\partial z}-\frac{\partial \overline{T^{\prime} w^{\prime}}}{\partial z} \\
\frac{\partial \bar{S}}{\partial t}=-\frac{\partial \overline{S^{\prime} w^{\prime}}}{\partial z} \\
\frac{\partial \overline{\mathbf{u}}_{H}}{\partial t}=-f \underline{k} \times \overline{\mathbf{u}}_{H}-\frac{\partial \overline{\mathbf{u}_{H}^{\prime} w^{\prime}}}{\partial z}
\end{gathered}
$$

where $T, S, \mathbf{u}_{H}$ and $w$ are the mean temperature, salinity, horizontal velocity and vertical velocity of the water column, respectively; $\overline{\mathrm{X}}$ denotes mean quantities and $\mathrm{X}^{\prime}$ denotes fluctuations around the mean; $\rho_{o}$ and $C_{p}$ are the reference density and the specific heat of the seawater, respectively; $F_{\text {sol }}$ is the solar irradiance arriving at sea surface; $f$ is the Coriolis parameter; $\underline{k}$ is the vertical unit vector. $I(z)$ is the fraction of $F_{\text {sol }}$ that penetrates to the depth $z$; it combines complementary "red" and "blue" fractions with faster and slower absorption respectively, following Paulson and Simpson (1977). The surface boundary conditions are

$$
\begin{gathered}
-\rho_{\mathrm{o}} \mathrm{C}_{\mathrm{p}} \overline{\mathrm{T}^{\prime} \mathrm{w}^{\prime}}=\mathrm{F}_{\mathrm{nsol}}=\mathrm{H}+\mathrm{LE}+\mathrm{F}_{\mathrm{ir}} \\
-\rho_{\mathrm{o}} \mathrm{C}_{\mathrm{p}} \overline{\mathrm{S}^{\prime} \mathrm{w}^{\prime}}=\mathrm{EP} \\
-\rho_{\mathrm{o}} \overline{\mathbf{u}_{\mathrm{H}}^{\prime} \mathrm{W}^{\prime}}=\tau
\end{gathered}
$$

where $\mathrm{F}_{\text {nsol }}$ represents the surface latent heat LE plus the sensible heat flux $\mathrm{H}$ plus the long-wave radiation $F_{i r}$. EP represents evaporation minus precipitation rate, and $\tau$ is the surface wind stress. Heat fluxes are positive downwards.

The vertical turbulence fluxes are parameterized using the turbulent viscosity/diffusivity concept:

$$
\begin{aligned}
-\overline{T^{\prime} w^{\prime}} & =K_{h} \frac{\partial \bar{T}}{\partial z} \\
-\overline{S^{\prime} w^{\prime}} & =K_{s} \frac{\partial \bar{S}}{\partial z}
\end{aligned}
$$




$$
-\overline{\mathbf{u}_{H}^{\prime} w^{\prime}}=K_{m} \frac{\partial \overline{\mathbf{u}}_{H}}{\partial z}
$$

Viscosity and diffusivities are related to length and velocity scales according to: $\mathrm{K}_{\mathrm{m}}=\mathrm{c}_{\mathrm{k}} \lambda_{\mathrm{k}} \mathrm{E}^{1 / 2}$ and $\mathrm{K}_{\mathrm{s}}=\mathrm{K}_{\mathrm{h}}=\mathrm{K}_{\mathrm{m}} / \mathrm{P}_{\mathrm{rt}}$ where $\mathrm{c}_{\mathrm{k}}$ is a constant to determined, $\lambda_{\mathrm{k}}$ is the mixing length, $\mathrm{E}$ is the turbulence kinetic energy (TKE), $\mathrm{E}=0.5\left(\mathrm{u}^{\prime 2}+\mathrm{v}^{\prime 2}+\mathrm{w}^{\prime 2}\right)$, and $\mathrm{P}_{\mathrm{rt}}$ is the turbulent Prandtl number, assumed to be 1 . To close the system TKE is determined from its balance equation:

$$
\frac{\partial \bar{E}}{\partial t}=-\frac{\partial}{\partial z}\left(\overline{E^{\prime} w^{\prime}}+\frac{\overline{p^{\prime} w^{\prime}}}{\rho_{o}}\right)-\overline{\mathbf{u}_{H}^{\prime} w^{\prime}} \cdot \frac{\partial \overline{\mathbf{u}}_{H}}{\partial z}+\overline{b^{\prime} w^{\prime}}-\varepsilon
$$

$p$ being the pressure; $\varepsilon$ is the dissipation rate of TKE; $b$ is the buoyancy, $b=g\left(\rho_{o}-\rho\right) / \rho_{o}$, where $g$ is gravity. For $\mathrm{E},(6)$ is subject to an input surface flux $\rho \mathrm{C}_{\mathrm{DKE}} \mathrm{W}^{3}$ proportional to stress $\times$ wind speed $\mathrm{W} ; \mathrm{C}_{\mathrm{DKE}}=0.63 \times 10^{-6}$. The density $\rho$ is determined by a state equation: $\rho=\rho_{\mathrm{o}}\left[1-\alpha\left(\mathrm{T}-\mathrm{T}_{\mathrm{o}}\right)\right.$ $+\beta\left(\mathrm{S}-\mathrm{S}_{\mathrm{o}}\right)$ ] where 0 refers to a reference state and $\alpha, \beta$ are respectively the coefficients of thermal expansion and haline contraction calculated according to Bryan and Cox (1972).

For the diffusivity of density, $\mathrm{K}_{\rho}=\mathrm{K}_{\mathrm{m}} / \mathrm{P}_{\mathrm{rt}}$. The turbulent diffusivity concept is also used to parameterise the vertical flux of turbulent kinetic energy

$$
-\overline{E^{\prime} w^{\prime}}-\frac{\overline{p^{\prime} w^{\prime}}}{\rho_{o}}=K_{e} \frac{\partial \bar{E}}{\partial z}
$$

with the usual assumption $K_{e}=K_{m}$. The dissipation rate is parameterised as follows: $\varepsilon=$ $\mathrm{c}_{\varepsilon} \mathrm{E}^{3 / 2} / \lambda_{\varepsilon}, \mathrm{c}_{\varepsilon}$ being a constant to be determined and $\lambda_{\varepsilon}$ the length scale for dissipation.

A difficulty of models that parameterise the turbulent viscosity based on the velocity and length scales is the determination of such scales, especially the length scale. In this model, very simple definitions of the length scales are used, avoiding a large number of coefficients and leading to very reasonable results as were obtained by Bougeault and Lacarrère (1989). The mixing length definitions are $\lambda_{\mathrm{k}}=\min \left(1_{\mathrm{u}}, 1_{\mathrm{d}}\right)$ and $\lambda_{\varepsilon}=\left(1_{\mathrm{u}} 1_{\mathrm{d}}\right)^{1 / 2}, \lambda_{\mathrm{k}}$ and $\lambda_{\varepsilon}$ being the length scales for mixing and dissipation respectively; $1_{\mathrm{u}}$ (upward) and $1_{\mathrm{d}}$ (downward) are obtained according to Bougeault and André (1986).

$$
\frac{g}{\rho_{o}} \int_{z}^{z+1_{u}}\left[\bar{\rho}(z)-\bar{\rho}\left(z^{\prime}\right)\right] d z^{\prime}=E(z) \quad \frac{g}{\rho_{o}} \int_{z-1_{d}}^{z}\left[\bar{\rho}(z)-\bar{\rho}\left(z^{\prime}\right)\right] d z^{\prime}=E(z)
$$

Two constants are to be determined, $\mathrm{c}_{\mathrm{k}}, \mathrm{c}_{\varepsilon}$. The determination of the constants is part of the model calibration. However, based on laboratory experiments, Bougeault and Lacarrère (1989) deduced that $\mathrm{c}_{\varepsilon}=0.7$ is an adequate value for simulations. The choice of $\mathrm{c}_{\mathrm{k}}$ is more difficult to justify from observations. Based on the definition of the mixing efficiency coefficient, $\gamma=R_{f} /(1-$ $R_{f}$ ), where

$$
R_{f} \equiv \overline{b^{\prime} w^{\prime}} /\left(\begin{array}{ll}
\overline{\mathbf{u}^{\prime} w^{\prime}} & \frac{\partial \overline{\mathbf{u}}_{H}}{\partial z}
\end{array}\right)
$$


is the flux Richardson number, it is possible to deduce that $c_{k}=0.15 c_{\varepsilon}$ (for details see Gaspar et al., 1990).

To avoid unrealistically small diffusion and dissipation rates in the pycnocline, Gaspar et al. (1990) suggested that a minimal value $E_{\min }$ for TKE should be imposed. To match the results of Gargett (1984) $\mathrm{E}_{\min }$ is set equal to $10^{-6} \mathrm{~m}^{2} \mathrm{~s}^{-2}$. This represents only a simple solution to obtain realistic diffusion rates in the thermocline. Gaspar et al. (1990) suggested that better results could probably be obtained by parameterising $E_{\min }$ as a function of internal wave activity and surface forcing.

Levitus (1982) July climatological profiles of temperature and salinity are imposed as initial conditions. The model runs from 1 June 1993 to 31 June 1995, with a time step of $900 \mathrm{~s}$. The vertical resolution is $5 \mathrm{~m}$ from the surface down to $1000-\mathrm{m}$ depth.

A first attempt to simulate the evolution of vertical structure of temperature revealed a general tendency to heat the upper ocean. Analyses of upper-ocean heat content and net heat flux through the sea surface led us to conclude that errors were caused by a systematic annual heat gain. Therefore an iterative method, adjusting simulated and observed sea surface temperature, was implemented in order to correct heat fluxes. Subsequently a simple adjustment -6 Watts $\mathrm{m}^{-2}$ to the surface input heat flux was found to give equally good results. The adjustments preserve good agreement between modelled and observed depth profiles of temperature, including the mixedlayer depth, and hence credibility of the modelled diffusion coefficient.

The mixed layer depth is in good agreement with temperature, nutrient and phytoplankton data obtained in the Goban Spur area. Temperature profiles (Fig. 9, 10) show that stratification is almost non-existent in the upper $200 \mathrm{~m}$ during winter (January to March). Temperature gradients appear in April and rapidly increase in May; the mixed-layer depth shoals during May-June. In early autumn the mixed layer starts to deepen consistently with the observations. Fig. 9 shows the seasonal evolution of temperature and Fig. 11 shows the turbulent eddy viscosity $K_{m}$ through depth and time. Strong diurnal variations of $K_{m}$ are filtered using weekly mean values. Values range from about $10^{-5} \mathrm{~m}^{2} \mathrm{~s}^{-1}$ in the strongest seasonal stratification to $10^{-1} \mathrm{~m}^{2} \mathrm{~s}^{-1}$ near the bottom of the surface mixed layer. For effectiveness in mixing nutrients through the water column (for example) these respective values are very small and very large; their significance for nutrient supply is considered further in the Discussion (section 4.3). The strongest vertical gradients appear at the base of the mixed layer, which shows a large variability during the year (also seen in Fig. 9).

\subsection{Effective lateral diffusivity related to current fluctuations}

From several dispersion experiments, Okubo (1971) estimates empirically

$$
\mathrm{K}_{\mathrm{H}}=0.000206 \mathrm{~L}^{1.15} \text { (in m, s) }
$$

where $\mathrm{L} \equiv 3 \times$ (root-mean-square spread of dispersed quantity). However, similarity theory for turbulence suggests a form

$$
\mathrm{K}_{\mathrm{H}} \propto\left(\mathrm{L}^{4} \varepsilon\right)^{1 / 3}
$$

$$
\sim 0.00928 \mathrm{~L}^{4 / 3} \text { (in m, s; empirically, atmosphere) }
$$

so fixing the proportionality constant if $\varepsilon$ is taken as $500 \mathrm{~mm}^{2} \mathrm{~s}^{-3}$ for the atmosphere. Taking instead $\varepsilon \sim 0.1\left(\hat{\mathrm{u}}^{2} / 2\right)^{3 / 2} / \mathrm{L}$ for marine application (e.g., Davies et al., 1995)

$$
\mathrm{K}_{\mathrm{H}} \sim 0.04 \hat{\mathrm{u} L}
$$

We remark that this extrapolation has involved some flexibility in the definition of $\mathrm{L}$ and corresponding uncertainty in the value of the coefficient, but the formula (12) for $\mathrm{K}_{\mathrm{H}}$ gives 
values that are reasonably consistent with several empirical estimates in the North Sea cited in Huthnance et al. (1993). Taking $\hat{\mathrm{u}}=0.1 \mathrm{~m} \mathrm{~s}^{-1}$ for the Goban Spur context gives estimates

$$
\mathrm{K}_{\mathrm{H}}=40,200 \mathrm{~m}^{2} \mathrm{~s}^{-1} \text { respectively for } \mathrm{L}=10,50 \mathrm{~km} \text {. }
$$

These estimates compare well with an alternative inference $\mathrm{K}_{\mathrm{H}}<100 \mathrm{~m}^{2} \mathrm{~s}^{-1}$ from persistence of current along the slope with width $\mathrm{L}=30 \mathrm{~km}$ (Pingree et al., 1999). From drogued-buoys set in the slope current west of Scotland and tracking generally northwards from there around Scotland, where the slope current and wind forcing are stronger ( $\hat{\mathrm{u}} \sim 0.2 \mathrm{~m} \mathrm{~s}^{-1}, \mathrm{~L}$ $\sim 100 \mathrm{~km}$ ) Burrows and Thorpe (1999) find $\mathrm{K}_{\mathrm{H}} \sim 350 \mathrm{~m}^{2} \mathrm{~s}^{-1}$. This range of values emphasises the dependence on context and especially the scale over which dispersion is considered.

\subsection{Shear-dispersion}

Dispersion may be enhanced by vertical shear, especially in shelf seas, to give

$$
\begin{aligned}
\mathrm{K}_{\mathrm{H}} & \propto(\mathrm{uh})^{2} / \mathrm{K}_{\mathrm{m}} \\
& \sim \mathrm{uh}
\end{aligned}
$$

(Bowden, 1965). Prandle (1984) modelled shear dispersion with the alternative form

$$
\mathrm{K}_{\mathrm{H}} \sim \mathrm{t}_{\mathrm{D}} \mathrm{u}^{2}
$$

where the coefficient $t_{D}=10^{3} \mathrm{~s}$ was found empirically to match observed spreading of caesium137.

For $\mathrm{h}=150 \mathrm{~m}$ on the shelf where these formulae are validated, we have in (13), (14)

$$
\begin{aligned}
u h & =15,30 \mathrm{~m}^{2} \mathrm{~s}^{-1} \\
t_{D} u^{2} & =10,40 \mathrm{~m}^{2} \mathrm{~s}^{-1} \text { respectively for } \mathrm{u}=0.1,0.2 \mathrm{~m} \mathrm{~s}^{-1} .
\end{aligned}
$$

These relatively low values - even for stronger tidal currents $\mathrm{O}\left(0.2 \mathrm{~m} \mathrm{~s}^{-1}\right)$ on the shelf - suggest that (tidal) shear dispersion in the Goban Spur context may be important only for (initial) small scales.

\subsection{Empirical estimation of lateral diffusivity}

Underway observations of near-surface temperature and salinity have been studied from 17 cruise segments straddling the continental slope near Goban Spur. The majority of these were in Autumn (September to early November) but there are records also from January 1994 and late June 1993. On this basis, the variability is widely distributed in length scale, across the range 1$50 \mathrm{~km}$ or more. About $2 \mathrm{~km}$ is typical for shorter-scale variability and there is no clear evidence of spatial or seasonal dependence (in this seasonally limited set). Warm temperature and higher salinity are usually correlated, but the ratio varies; there is approximate density compensation over the shelf and upper-most slope, whereas temperature dominates further off-shelf. The clearest signal is a transition to fresher (and cooler) water on the shelf. Typically this transition is in a distance $\mathrm{O}(2 \mathrm{~km})$, the temperature change is $0.2^{\circ} \mathrm{C}$ or more and the salinity change is 0.1 or more; it occurs several kilometres on the shelf side of the $200-\mathrm{m}$ depth contour with a couple of exceptions where it is a few kilometres on the ocean side of $200 \mathrm{~m}$.

Satellite images also show variability on a range of scales with varying persistence, indicating the spatial scales of dominant contributions to variability. The shortest scales tend not to persist from day to day. Persistence of features between successive images is an indicator of (lack of) effective lateral diffusivity $\mathrm{K}_{\mathrm{H}}$. Hence $\mathrm{K}_{\mathrm{H}}$ may be estimated from the scale $\mathrm{L}$ at which 
coherence is retained between successive image spectra separated by a time interval $\Delta \mathrm{t}$. Based on $\partial \mathrm{C} / \partial \mathrm{t}=\partial / \partial \mathrm{x}\left(\mathrm{K}_{\mathrm{H}} \partial \mathrm{C} / \partial \mathrm{x}\right)$, the estimate is $\mathrm{K}_{\mathrm{H}} \sim \mathrm{L}^{2} / \Delta \mathrm{t}$. On the basis that 2-km scales $\mathrm{L}$ are substantially diffused in time $\Delta \mathrm{t} \sim 10^{5} \mathrm{~s} \sim 1$ day, then $\mathrm{K}_{\mathrm{H}}$ is about $40 \mathrm{~m}^{2} \mathrm{~s}^{-1}$ as before. However, the transition to fresher water on the shelf is clearly persistent on much longer time scales despite the similar 2-km length scale. This persistence is presumably associated with continuing inshore sources of fresh water that resist shelf-ward salinity flux from the ocean. Thus we have a steadystate salinity balance $\left(\mathrm{uS}-\mathrm{K}_{\mathrm{H}} \mathrm{S}_{\mathrm{x}}\right)_{\mathrm{x}}=0$; hence

$$
\begin{aligned}
& \mathrm{uS}-\mathrm{K}_{\mathrm{H}} \mathrm{S}_{\mathrm{x}}=0 \text { (for zero salinity flux at coast) } \\
& \text { or } \quad \mathrm{S}=\mathrm{S}_{0} \exp \left(\int \mathrm{u} / \mathrm{K}_{\mathrm{H}} \mathrm{dx}\right)
\end{aligned}
$$

(15) gives an off-shelf scale $K_{H} / u=2 \mathrm{~km}$ if (for example) $\mathrm{u}=-0.01 \mathrm{~m} \mathrm{~s}^{-1}$ and $\mathrm{K}_{\mathrm{H}}=20 \mathrm{~m}^{2} \mathrm{~s}^{-1}$. Note that a localised front (salinity change) is associated with localised off-shelf flow -u. We have no clear measurement for $u$ but a dynamical expectation of localised near-surface offshore flow of fresher water over more saline oceanic water.

To summarise, the evidence suggests horizontal diffusivities 20 to $40 \mathrm{~m}^{2} \mathrm{~s}^{-1}$ on rather local scales 2 to $10 \mathrm{~km}$ over Goban Spur. This excludes the effects of larger-scale motions that one might expect to consider deterministically as advection rather than stochastically as diffusion.

\section{Synthesis and discussion}

\subsection{Mean currents (seasonal variation)}

It is often asked whether the along-slope flow is continuous. In fact "continuous" is an umbrella for three questions. Firstly (in the weakest sense of continuity) pulses of flow may propagate along the slope. This may be the hardest aspect to show by observation, because of the simultaneous spatial and temporal coverage of measurements required. However, the propagation of signals as waves along the continental shelf and slope (poleward at the eastern side of the ocean) is well established (e.g., Huthnance et al., 1986). Secondly, is the slope current everywhere present? The answer to this is, certainly not all the time. In particular, the mooring in $996 \mathrm{~m}$ on Goban Spur shows periods when the flow reverses or ceases to be along the slope. However, the evidence points to a majority of flow over the slope being poleward around the north-west European shelf; all observed locations on this slope have a long-term average flow along it in this sense, so far as measurements determine it. Thirdly, the strongest form of continuity is for elements of water to be transported along the slope. This entails along-slope flow at all points of the path of transported water. Nevertheless, the OMEX drogue track (section 3.2) suggests such strong continuity in this sense, at least from south-west of Ireland polewards. It may be reinforced in winter when prevailing south-westerly winds favour anticyclonic circulation around the British Isles. (Goban Spur may break this continuity; see below).

Models tend to support continuity in all these senses. Fig. 14 of Pingree and Le Cann (1989) shows "JEBAR" - forced flow "northwards" along the slope west of Britain from $45^{\circ}$ to $62^{\circ} \mathrm{N}$. Bartsch and Coombs (1997) modelled the dispersion of blue whiting larvae. These showed a broad division with a net transport to the north from north of Porcupine Bank but to the southeast from south of Porcupine Bank. This tends to confirm the divided pattern of seasonal (spring) variation in the observed mean flows (Fig. 3).

It is expected that baroclinic flow with small Rossby radius of internal deformation $R_{I}$ (a few kilometres) should follow the depth contours around Goban Spur, which also have a radius of curvature greater than an inertial radius $|\mathbf{u}| / \mathrm{f}$ to avoid inertial "overshoot". However, to the extent that the slope current is barotropic, the larger shelf-width and barotropic Rossby radius scales come into play. Goban Spur may then be regarded as a topographic irregularity; the flow 
is perturbed; this is often expressed as scattering into coastal-trapped waves according to those waves' dynamics. In fact Pingree et al. (1999) show evidence of "overshoot" at Goban Spur: a satellite image of colder surface water projecting oceanwards by continuing the "upstream" along-slope line from either side of the Spur; similar preferential directions (along-slope) in the currents at PML154 over the Spur, according to season.

The cause of the SOMA (seasonal) effect in the along-slope flow, and its apparent northsouth separation (spring) and convergence (autumn) at Porcupine Bank, warrant more investigation. This should include the many current measurements in the continuing mean flow around Scotland (as well as relation to possible forcing mechanisms) and is beyond the scope of this paper.

\subsection{Physical process contributions to circulation, exchange and mixing}

The following tables show estimates of process contributions over Goban Spur, for processes relevant there. Estimates are often based on earlier literature as indicated in the tables and derived as discussed in Huthnance (1995). Notation is defined in Table 1, together with estimated values appropriate to the area of Goban Spur and sources for those estimates.

Estimated contributions to circulation are shown in Table 3.

Hence JEBAR and wind forcing, eddy momentum transfer and tides may be significant contributions to circulation, and possibly also eddies. Note that the JEBAR effect will be reduced by a factor (meridional extent / along-slope distance) in the generation region for the slope current (to the south east). The steady-wind response appears large, but will rarely occur, taking a time $\mathrm{h} / \mathrm{k} \sim 6$ days to evolve (for $\mathrm{h}=150 \mathrm{~m}$; longer for greater depths); the wind is rarely steady for so long.

Estimated contributions to ocean-shelf exchange are shown in Table 4.

The largest contributions are therefore from tides, albeit reversed every $1 / 4$ day so that the net exchange is much smaller. Significant contributions may be expected also from wind-driven flow (including waves), ridge-associated upwelling, cross-frontal exchange, surface and internal waves; intermittently from eddies and from cascading in winter.

Estimated contributions to energy potentially available for mixing are shown in Table 5.

Whereas surface waves are important to surface mixing with very large estimates of energy potentially available, internal waves are significant at greater depths where surface wave effects do not penetrate.

Mixing is important to development of the seasonal thermocline. This shows some "average" aspects common between the years, largely reflected in the model run for 1994. However, the storm during 5-8 September 1995 produced a marked deepening of the upper mixed layer and redistribution of primary production. These effects demonstrate the inadequacy of any "average" mixing intensity for describing short-term conditions (as observed on any one "seasonal" cruise). The modelled turbulent viscosity and mixing coefficients implicitly take account of wind and wave contributions through the applied surface stress. However, there is no specific account of internal waves (not represented in a 1-D model; they would at least modify the need for $\mathrm{E}_{\min }$ as a lower limit to the model's turbulence).

The model results show highly contrasted values through the vertical. Values near the bottom of the mixed layer are very large, but may not need to be known with any precision if their effect is to provide vertical mixing which cannot be more effective with any larger value. However, the small values in the thermocline are critical to the transport of nutrients to the euphotic zone. The inference from September 1995 is that before the storm a continuing small amount of mixing within the thermocline allowed some nutrient entrainment from below and hence some continuing production. Mixing during the storm may be most relevantly quantified as the entrainment into the surface mixed layer of another $20 \mathrm{~m}$ approximately, accompanied by 
its nutrients. Clearly the modelling of such a substantial discrete event requires forcing by the "real" meteorological data for the period in question.

\subsection{Nitrogen available via vertical mixing for new production}

We saw in section 3.8 that values of vertical diffusivity range from about $10^{-5} \mathrm{~m}^{2} \mathrm{~s}^{-1}$ in the strongest seasonal stratification to $10^{-1} \mathrm{~m}^{2} \mathrm{~s}^{-1}$ near the bottom of the surface mixed layer, claiming that these values are effectively very small and very large, respectively. These values are now considered in an application of interest in OMEX: vertical mixing of nutrients to supply primary production in the surface mixed layer. As this is a context for the estimates of vertical diffusivity, it is consistent here to focus on the vertical mixing; also relevant is the note in section 3.7 of little evidence of any consistent relation between mixed-layer depth and location over the shelf, slope or deeper ocean as a basis for lateral transport of nutrients (as distinct from organic carbon in section 1.2). Overall, we suggest that nitrogen available for new production should comprise

(a) spring surface mixed layer depth $\times$ nitrogen value

(as taken up by the spring bloom)

+ (b) summer diffusive flux through the thermocline

(summer duration $\times \mathrm{K}_{\mathrm{s}} \times \Delta$ nitrogen value $/ \Delta \mathrm{z}$ )

$+(\mathrm{c})$ autumn entrained depth until production stops $\times$ nitrogen value

(as the thermocline deepens, until there is not enough light).

We suppose (as measurements suggest) that the "nitrogen value" (from nitrate and nitrite) is uniform in the relevant top $100 \mathrm{~m}$, except when depleted by production. This value is then used in (a) and (c), and as $\Delta$ nitrogen in (b) representing the difference below-above the thermocline that drives the summer diffusive flux through the thermocline. The layer that actually gets depleted in spring is an early (large) mixed-layer depth; a few CTD profiles with nitrate and nitrite samples suggest that $60 \mathrm{~m}$ may be a reasonable estimate in (a). In (b), from the model, $\mathrm{K}_{\mathrm{s}}$ is less than $0.0001 \mathrm{~m}^{2} \mathrm{~s}^{-1}$ over a thermocline depth $\Delta \mathrm{z} \sim 50 \mathrm{~m}$ and summer is less than $10^{7} \mathrm{~s}$ duration. For (c), we find a mixed layer deepening of about $30 \mathrm{~m}$; this refers to the top of the thermocline whereas the entrainment is at the base and nutrients are already depleted at the top; the entrained depth is probably less than this.

Hence the calculation (in $\mathrm{m}$ depth, to be multiplied by "nitrogen value" in each case) is
(a) 60
(b) $+1000 / 50 \quad$ (or less)
(c) $+30 \quad$ (or less)

or about $100 \mathrm{~m}$ "equivalent entrained depth" of nitrogen.

It is interesting that on this basis the summer "diffusion" does not seem to contribute greatly, i.e., summer production is driven by ammonia not nitrate, with low $f$-ratios; see Rees et al. (1999), Joint et al. (2000). Uncertainty in the summer diffusion value may not be very significant if it is sufficiently small. This attaches importance to the additional internal mixing from internal waves on the summer thermocline. Jeans (1998) estimates effective $\mathrm{K}_{\mathrm{s}}$ values $0.0014,0.004 \mathrm{~m}^{2} \mathrm{~s}^{-1}$ (mean, peak values) for the Portuguese shelf having internal waves of size comparable with those over Goban Spur. Such values could raise the "equivalent entrained depth" to $300 \mathrm{~m}$ locally. An alternative calculation equates the internal tidal energy dissipation (Table 5), multiplied by an efficiency factor, with the work to lift an entrained depth $\mathrm{d}$ through the thermocline thickness $\Delta \mathrm{z}$ :

$$
(\rho g \Delta \rho / \rho)<\zeta^{2}>\lambda / L_{T} \times \text { efficiency }=g \Delta \rho d \Delta z \text { on each tide }
$$


Through a summer of 230 tides this gives an aggregate entrained depth

$$
\mathrm{d}=230<\zeta^{2}>\lambda /\left(\Delta \mathrm{z} \mathrm{L}_{\mathrm{T}}\right) \times \text { efficiency }
$$

Again for the Portuguese shelf, Jeans (1998) estimates an internal dissipation rate $\sim 0.1$ watts $\mathrm{m}^{-2}$ and rate of working on potential energy $\sim 0.02$ watts $\mathrm{m}^{-2}$ (efficiency $18 \%$ ) corresponding to an equivalent entrained depth $400 \mathrm{~m}$, if here $\mathrm{g} \Delta \rho=10 \mathrm{~kg} \mathrm{~m}^{-2} \mathrm{~s}^{-2}$ corresponding to $13^{\circ}-18^{\circ} \mathrm{C}$ across the thermocline and $\alpha=0.0002\left({ }^{\circ} \mathrm{C}\right)^{-1}, \Delta \mathrm{z}=50 \mathrm{~m}$, summer duration $=10^{7} \mathrm{~s}$. Then these numbers in (16) correspond to

$$
<\zeta^{2}>\lambda / L_{\mathrm{T}}=\mathrm{d} \Delta \mathrm{z} /(230 \text { efficiency }) \sim 500 \mathrm{~m}^{2}
$$

in the Portuguese context, compared with observed $\left\langle\zeta^{2}\right\rangle \sim 100 \mathrm{~m}^{2}$. Hence we suggest that $\left\langle\zeta^{2}\right\rangle$ should represent the full internal tide and $\lambda$ should take its maximal value $\mathrm{L}_{\mathrm{T}}$ (in one tidal period the wave energy is dispersed over at least its wavelength, i.e., the distance that it propagates). Elsewhere, smaller efficiencies may prevail, e.g., 5.6\% (Stigebrandt and Aure, 1989), 7\% on the Malin-Hebrides shelf west of Scotland (Inall et al., 1999). Hence for Goban Spur, with $\left\langle\zeta^{2}\right\rangle=$ $100 \mathrm{~m}^{2}, \lambda=\mathrm{L}_{\mathrm{T}}=50 \mathrm{~km}$, thermocline thickness $\Delta \mathrm{z}=50 \mathrm{~m}$ and efficiencies 5.6 to $18 \%$ we estimate $\mathrm{d}=26$ to $83 \mathrm{~m}$, a moderate but significant contribution to nutrient mixing up to the surface mixed layer. Further south-east at the Celtic Sea shelf break where $\left\langle\zeta^{2}\right\rangle=900 \mathrm{~m}^{2}$, if again $\lambda=\mathrm{L}_{\mathrm{T}}$, thermocline thickness $\Delta \mathrm{z}=50 \mathrm{~m}$ and efficiencies are 5.6 to $18 \%$, then the corresponding estimate over the summer is $d=230$ to $745 \mathrm{~m}$.

\section{Concluding remarks}

This paper has been concerned with physical processes and especially their contributions to shelf-ocean exchange and mixing, using the most relevant evidence in the Goban Spur area.

\subsection{Characteristics of the physical regime in the Goban Spur region}

The along-slope flow, typically $\mathrm{O}\left(0.05 \mathrm{~m} \mathrm{~s}^{-1}\right)$, is reduced or even reversed in spring, is generally weaker than at some other margin sectors owing to the non-meridional alignment and indentations in the Celtic Sea slope, and may sometimes overshoot rather than follow the depth contours around Goban Spur.

Tidal currents are $\mathrm{O}\left(0.2 \mathrm{~m} \mathrm{~s}^{-1}\right)$ on the adjacent shelf but $\mathrm{O}\left(0.1 \mathrm{~m} \mathrm{~s}^{-1}\right)$ or less over most of Goban Spur; they increase to the south east; they make an important contribution to the total current variance, turbulence and mixing in the area, especially over the shelf and towards the south east in the Celtic Sea and over the adjacent slope. A more specific contribution to internal mixing is made by internal tides, especially to the south east.

Other (wind- and eddy-forced) contributions to the currents are typically $\mathrm{O}\left(0.1 \mathrm{~m} \mathrm{~s}^{-1}\right)$ or less, except on the shelf, and decrease downwards.

Wind-, tide- and wave-forced currents are probably the most consistent agents of crossslope exchange $\mathrm{O}\left(1 \mathrm{~m}^{2} \mathrm{~s}^{-1}\right)$, with topographic effects important locally (canyons, spurs).

Stratification starts intermittently from late March until early June, becomes shallower through June and deepens by September. In 1995 one storm on 5-8 September roughly doubled the upper mixed-layer depth to $>40 \mathrm{~m}$, reinstating maximal primary production there by reintroducing nutrients to the surface layer.

Eddy diffusion coefficients, estimated with the 1-D eddy kinetic energy model, show a seasonal variation, mostly induced by variable surface buoyancy fluxes.

Mixing is intermittent, dominated by surface inputs (wind effects); towards the south east, internal waves of tidal origin are increasingly important for mixing across the thermocline. In the 
context of nutrient provision for primary production in the upper mixed layer, diffusion through the summer thermocline appears to be small unless internal waves strongly increase mixing.

\subsection{Further scope}

The numerical model's turbulence kinetic energy could be constrained to exceed a set minimum related to surface forcing and internal waves, and bottom-induced mixing included over the shelf.

Other possible approaches to defining the physical regime include small-scale shear from ship-borne ADCP data; combining coincident current, $\mathrm{CTD}(\mathrm{z})$ and remote-sensing (horizontal structure) data to estimate cross-slope transports; estimating $\mathrm{K}_{\mathrm{H}}$ from constituent distributions and from models resolving the main contributing processes; estimating cross-slope exchange for the Celtic Sea as a whole from a Celtic Sea budget.

A lateral diffusivity estimate (cf. section 3.11) might also be made from successive ship tracks with underway sampling or from an individual track if a biological growth rate provides the time scale $\Delta \mathrm{t}$ (Tett and Edwards, 1984).Phytoplankton patchiness can show the spectrum of physical variability, e.g., Gower et al. (1980). The estimate depends on vertical diffusion if the patchiness varies with depth.

Drogued buoy tracks can test the idea that the paths of along-slope flows approaching a spur may cross through "overshooting" off the spur. Models can investigate effects of spurs on geostrophic slope currents and the possibilites of associated eddy formation and cross-contour flow.

OMEX and other observations of intermediate nepheloid layers put bounds on the ratio $\mathrm{K}_{\mathrm{s}} / \mathrm{K}_{\mathrm{H}}$, as discussed in a companion paper by McCave et al. (2000) and in Amin and Huthnance (1999).

\section{Acknowledgements}

This work was supported by the EU through the MAST programme, contract MAS3-CT96-0056 (Ocean Margin Exchange - OMEX). The UK Ministry of Defence also supported PML work at sea. Provision and discussion of remote-sensed data by Steve Groom (PML), and access to currentmeter data from all sources with the help of the British Oceanographic Data Centre is gratefully acknowledged. Toby Sherwin and Mark Inall contributed helpfully to the discussion of internal wave mixing in summer. The paper has been improved by reviewers' comments.

\section{References}

Amin, M., Huthnance, J.M., 1999. The pattern of cross-slope depositional fluxes. Deep-Sea Research I 46, 1565-1591.

Antia, A.N., Maaßen J., , Vo $\beta$ M., Scholten, J. Groom, S., Miller, P., 2000. Spatial and qualitative patterns of particle flux at the European continental margin. Deep-Sea Research II, this issue.

Arhan, M., Colin de Verdière, A., Mémery, L., 1994. The eastern boundary of the subtropical North Atlantic. Journal of Physical Oceanography 24, 1295-1316.

Awaji, T., Akitomo, K., Imasato, N., 1991. Numerical study of shelf water motion driven by the Kuroshio: barotropic model. Journal of Physical Oceanography 21, 11-27.

Baines, P.G., 1986. Internal tides, internal waves, and near inertial motions. In: Mooers, C.N.K. (Ed.), Baroclinic Processes on Continental Shelves: Coastal and Estuarine Sciences 3, 19-31. American Geophysical Union, Washington DC.

Bartsch, J., Coombs, S., 1997. A numerical model of the dispersion of blue whiting larvae, Micromesistius poutassou (Risso) in the eastern North Atlantic. Fisheries Oceanography 6, 141-154. 
Batchelor, G.K., 1950. The application of the similarity theory of turbulence to atmospheric diffusion. Quarterly Journal of the Royal Meteorological Society 76, 133-146.

Bersch, M., 1995. On the circulation of the northeastern North Atlantic. Deep-Sea Research I 42, 1583-1607.

Biscaye, P.E., Flagg, C.N., Falkowski, P.G., 1994. The Shelf Edge Exchange Processes experiment, SEEP-II: an introduction to hypotheses, results and conclusions. Deep-Sea Research II 41, 231-252.

Booth, D.A., 1988. Eddies in the Rockall Trough. Oceanologica Acta, 11, 213-219.

Booth, D.A., Ellett, D.J., 1983. The Scottish continental slope current. Continental Shelf Research 2, 127-146.

Borresen, J.A., 1987. Wind atlas for the North Sea and Norwegian Sea. Norwegian University Press, 184pp.

Bougeault, P., André, J.C., 1986. On the stability of the third-order turbulence closure for the modeling of the stratocumulus-topped boundary. Journal of the Atmospheric Sciences 43, 1574-1581.

Bougeault, P., Lacarrère. P. 1989. Parameterization of orography-induced turbulence in a mesobeta scale model. Monthly Weather Review 117, 1872-1890.

Bowden, K.F., 1965. Horizontal mixing in the sea due to a shearing curent. Journal of Fluid Mechanics 21, 83-95.

Brink, K.H., Cowles, T.J., 1991. The coastal transition zone program. Journal of Geophysical Research 96, 14637-14647.

Bryan, K., Cox, M.D., 1972. An approximate equation of state for numerical models of ocean circulation. Journal of Physical Oceanography 2, 510-514.

Burrows, M., Thorpe, S.A., 1999. Drifter observations of the Hebrides slope current and nearby circulation patterns. Annales Geophysicae 17, 280-302.

Cartwright, D.E., Edden, A.C., Spencer, R., Vassie, J.M., 1980. The tides of the North East Atlantic Ocean. Philosophical transactions of the Royal Society of London A298, 87-139.

Chapman, D.C., Lentz, S.J., 1997. Adjustment of stratified flow over a sloping bottom. Journal of Physical Oceanography 27, 341-356.

Chatwin, P.G., 1996. Near-bed flows and sediment movement on the continental slope. PhD thesis, Institute of Marine studies, University of Plymouth, unpublished.

Cooper, L.N.H., Vaux, D., 1949. Cascading over the continental slope of water from the Celtic Sea. Journal of the Marine Biological Association of the U.K. 28, 719-750.

Davies, A.M., Luyten, P.J., Deleersnijder, E., 1995. Turbulence energy models in shallow sea oceanography. In: Lynch, D.R., Davies, A.M. (Eds.), Quantitative skill assessment for coastal ocean models: Coastal and Estuarine Studies 47, 97-123.

(DEn) Department of Energy, 1989. Offshore installations: guidance on design and construction. Meteorological and Oceanographic design parameters. Part 2, Section 2: Environmental Considerations. PEA/68/35/1, 1989, 72pp.

Denbo, D.W., Allen, J.S., 1983. Mean flow generation on a continental margin by periodic wind forcing. Journal of Physical Oceanography 13, 78-92.

Dickson, R.R., 1989. Flow statistics from long-term current-meter moorings. The global data-set in January 1989. World Climate Research Programme WCRP - 30 (WMO/TD - No. 337): WOCE report 46/90.

Dickson, R.R., Gurbutt, P.A., Pillai, V.N., 1980. Satellite evidence of enhanced upwelling along the European continental slope. Journal of Physical Oceanography 10, 813-819.

Dickson, R.R., Gould, W.J., Muller, T.J., Maillard, C., 1985. Estimates of the mean circulation in the deep (2,000 m) layer of the Eastern North Atlantic. Progress in Oceanography 14, 103 127. 
Dickson, R.R., McCave, I.N., 1986. Nepheloid layers on the continental slope west of Porcupine Bank. Deep-Sea Research 33, 791-818.

Draper, L., 1991. Wave climate atlas of the British Isles. Offshore Technology Report OTH 89 303,11 pp \& plates.

Esbensen, S., Kushnir, Y., 1981. Global heat flux and wind stress. Oregon State University Climate Research Institute, Reports 26, 29.

Flather, R.A., 1981. Results from a model of the North East Atlantic relating to the Norwegian Coastal Current. In: Saetre, R., Mork, M. (Eds.), The Norwegian Coastal Current. University of Bergen, pp. 427-458.

Flather, R.A., Proctor, R., Wolf, J., 1991. Oceanographic forecast models. In: Farmer, D.G., Rycroft, M.J. (Eds.), Computer modelling in the environmental sciences. Clarendon Press, Oxford, pp. 15-30.

Fuglister, F.C., 1960. Atlantic Ocean Atlas. Woods Hole Oceanographic Institution, Atlas Series, I, 209pp.

Galperin, B., Kantha, L.H., Hassid, S., Rosati, A., 1988. A quasi-equilibrium turbulent energy model for geophysical flows. Journal of the Atmospheric Sciences 45, 55-62.

Garcia-Soto, C., Pingree, R.D., 1998. Shelf-break / slope chlorophyll-a distributions: late autumn distribution and seasonality of chlorophyll-a at the shelf-break / slope region of the Armorican and Celtic shelf. Journal of the Marine Biological Association of the UK. 78, 1-17.

Gargett, A.E., 1984. Vertical eddy diffusivity in the ocean interior. Journal of Marine Research 42, 359-393.

Garrett, C.J.R., 1979. Topographic Rossby waves off East Australia; identification and role in shelf circulation. Journal of Physical Oceanography 9, 244-253.

Garrett, C., Gilbert, D., 1988. Estimates of vertical mixing by internal waves reflected off a sloping bottom. In: Small-scale turbulence and mixing in the ocean. Proceedings of the $19^{\text {th }}$ International Liège Colloquium on Ocean Hydrodynamics. Elsevier Oceanography Series, 46, 405-423

Garrett, C., MacCready, P., Rhines, P., 1993. Boundary mixing and arrested Ekman layers: rotating stratified flow near a sloping boundary. Annual Review of Fluid Mechanics 25, 291323.

Gaspar, P.G., Grégoris, Y., Lefèvre, J.-M., 1990. A simple eddy kinetic energy model for simulations of the oceanic vertical mixing: tests at station Papa and Long-Term Upper Ocean Study site. Journal of Geophysical Research 95, 16179-16193.

Gower, J.F.R., Denman, K.L., Holyer, R.J., 1980. Phytoplankton patchiness indicates the fluctuation spectrum of mesoscale oceanic structure. Nature 288, 157-159.

Haidvogel, D.B., Brink, K.H., 1986. Mean currents driven by topographic drag over the continental shelf and slope. Journal of Physical Oceanography 16, 2159-2171.

Harvey, J., Glynn, S., 1985. Water mass structure and transport in the Tourbillon eddy. Deep-Sea Research 32, 675-695.

Heathershaw, A.D., 1985. Some observations of internal wave current fluctuations at the shelfedge and their implications for sediment transport. Continental Shelf Research 4, 485-493.

Hill, A.E., Souza, A.J., Jones, K., Simpson, J.H., Shapiro, G., McCandliss, R., Wilson, H., Leftley, J., 1998. The Malin cascade in winter 1996. Journal of Marine Research 56, 87-106.

Holloway, G., 1987. Systematic forcing of large-scale geophysical flows by eddy-topography interaction. Journal of Fluid Mechanics 184, 463-476.

Holt, J.T., Thorpe, S.A., 1997. The propagation of high frequency internal waves in the Celtic Sea. Deep-Sea Research 44, 2087-2116.

Howarth, M.J., 1990. Atlas of tidal elevations and currents around the British Isles. UK Department of Energy publication OTH 89 293, HMSO, London. 
Huthnance, J.M., 1981. Waves and currents near the continental shelf edge. Progress in Oceanography 10, 193-226.

Huthnance, J.M., 1984. Slope currents and "JEBAR". Journal of Physical Oceanography 14, $795-$ 810.

Huthnance, J.M., 1986. The Rockall slope current and shelf-edge processes. In: Mauchline, J. (Ed.), The oceanography of the Rockall Channel. Proceedings of the Royal Society of Edinburgh 88B, 83-101.

Huthnance, J.M., 1987. Effects of longshore shelf variations on barotropic continental shelf waves, slope currents and ocean modes. Progress in Oceanography 19, 177-220.

Huthnance, J.M., 1995. Circulation, exchange and water masses at the ocean margin: the role of physical processes at the shelf edge. Progress in Oceanography 35, 353-431.

Huthnance, J.M., Mysak, L.A., Wang, D.-P. 1986. Coastal trapped waves. In: Mooers, C.N.K. (Ed.), Baroclinic processes on continental shelves. AGU, Washington, D.C. Coastal and Estuarine Sciences 3, 1-18.

Huthnance, J.M., Allen, J.I., Davies, A.M., Hydes, D.J., James, I.D., Jones, J.E., Millward, G.E., Prandle, D., Proctor, R., Purdie, D.A., Statham, P.J., Tett, P.B., Thomson, S., Wood, R.G., 1993. Towards water quality models. Philosophical Transactions of the Royal Society of London A343, 569-584.

Hydes, D.J., Le Gall, A.C., Miller, A.E.J., Brockmann, U., Raabe, T., S. Holley, AlvarezSalgado, X., Antia, A., Balzer, W., Chou, L., Elskens, M., Helder, W., Joint, I., , Orren, M., 2000. Supply and demand of nutrients and dissolved organic matter at and across the NW European shelf break in relation to hydrography and biogeochemical activity. Deep Sea Research Part II, this issue.

ICES, 1962. Mean monthly temperature and salinity of the surface layer of the North Sea and adjacent waters from 1905 to 1954 . ICES, Charlottenlund, Denmark.

Inall, M.E., Rippeth, T.P., Sherwin, T.J., 1999. The impact on non-linear waves on the dissipation of internal tidal energy at a shelf break. Journal of Geophysical Research, to appear.

IOC, IHO, BODC, 1997. GEBCO-97: the 1997 edition of the GEBCO digital atlas. Published on behalf of the Intergovernmental Oceanographic Commission (of UNESCO) and the International Hydrographic Organisation as part of the General Bathymetric Chart of the Oceans (GEBCO). British Oceanographic Data Centre, Birkenhead. Includes a CD-ROM. Web information at http://www.nbi.ac.uk/bodc/gebco.html.

James, I.D., 1980. Thermocline formation in the Celtic Sea. Estuarine and Coastal Marine Science 10, 597-607.

Jeans, D.R.G., 1998. A nonlinear internal tide on the Portuguese shelf. PhD thesis, School of Ocean Sciences, University of Wales Bangor, unpublished.

Joint, I., Wollast, R., Chou, L., Batten, S., Elskens, M., Edwards, E., Hirst, A., Burkill, P., Groom, S., Gibb, S., Miller, A., Hydes, D., Dehairs, F., Antia, A., Barlow, R., Rees, A., Pomroy, A., Brockmann, U., Cummings, D., Lampitt, R., Loijens, M., Mantoura, F., Miller, P., Raabe, T., Alvarez-Salgado, X., Stelfox, C., Woolfenden, J., 2000. Pelagic production at the Celtic Sea shelf break. Deep-Sea Research II, this issue.

Kenyon, K.E., 1969. Stokes drift for random gravity waves. Journal of Geophysical Research 74, 6991-6994.

Killworth, P.D., 1978. Coastal upwelling and Kelvin waves with small topography. Journal of Physical Oceanography 8, 188-205.

Kondratyev, K.Y., 1969. Radiation in the Atmosphere. Academic, San Diego.

Kwong, S.C.M., Davies, A.M., Flather, R.A., 1997. A three-dimensional model of the principal tides on the European shelf. Progress in Oceanography, 39, 205-262. 
Large, W.G., Pond, S., 1981. Open ocean momentum flux measurements in moderate to strong winds. Journal of Physical Oceanography 11, 324-366.

Large, W.G., Pond, S., 1982. Sensible and latent heat flux measurements over the ocean. Journal of Physical Oceanography 12, 464-482.

Largier, J.L., 1990. Deep surface mixed layers on the continental shelf. Continental Shelf Research 10, 759-776.

Levitus, S., 1982. Climatological atlas of the world ocean. NOAA Professional Paper 13, 173pp.

Levitus, S., Boyer, T.P., 1994. World Ocean Atlas 1994. Volume 4: Temperature. NOAA Atlas NESDIS 4, 117pp.

Levitus, S., Burgett, R., Boyer, T.P., 1994. World Ocean Atlas 1994. Volume 3: Salinity. NOAA Atlas NESDIS 3, 99pp.

Lozier, M.S., Owens, W.B., Curry, R.G., 1995. The climatology of the North Atlantic. Progress in Oceanography 36, 1-44.

McCave, I.N., Hall, I.R., Antia, A.N., Chou, L. Dehairs, F., Lampitt, R.S., Thomsen, L., van Weering, T.C.E., Wollast, R., 2000. Distribution, composition and flux of particulate material over the European margin at $47-50^{\circ}$ N. Deep Sea Research Part II, this issue.

Mellor, G.L., Wang, X.H., 1996. Pressure compensation and the bottom boundary layer. Journal of Physical Oceanography 26, 2214-2222.

Melville, W.K., 1994. Energy dissipation by breaking waves. Journal of Physical Oceanography 24, 2041-2049.

Miller, P., Groom, S., McManus, A., Selley, J., Woolfenden, J., Blewett, J., Osborne, L., 1996. Remote sensing activities in OMEX. Ocean Margin Exchange OMEX Final Report B, 265317. A "movie" sequence is available on-line at http://www.npm.ac.uk/rsdas/omex/eddy.

New, A.L., 1988. Internal tidal mixing in the Bay of Biscay. Deep-Sea Research 35, 691-709.

New, A.L., Pingree, R.D., 1990. Evidence for internal tidal mixing near the shelf break in the Bay of Biscay. Deep-Sea Research 37, 1783-1803.

Norris, S., MacDougall, N., 1986. Current-meter observations near the Porcupine Bank, 19811983. MAFF, Lowestoft, UK. Fisheries Research Data Report 8, 103pp.

Okubo, A., 1971. Oceanic diffusion diagrams. Deep-Sea Research 18, 789-802.

Paulson, C.A., Simpson, J.J., 1977. Irradiance measurements in the upper ocean. Journal of Physical Oceanography, 7, 952-956.

Pingree, R.D., 1979. Baroclinic eddies bordering the Celtic Sea in late summer. Journal of the Marine Biological Association of the U.K. 59, 689-698.

Pingree, R.D., 1984. Some applications of remote sensing to studies in the Bay of Biscay, Celtic Sea and English Channel. In: Nihoul, J.C.J. (Ed.), Remote Sensing of Shelf Seas Hydrodynamics. Proceedings of the $15^{\text {th }}$ international Liège Colloquium. Amsterdam: Elsevier Oceanography Series 38, 287-315.

Pingree, R.D., 1988. Internal tidal oscillations and water column instability in the upper slope region of the Bay of Biscay. In: Nihoul, J.C.J., Jamart, B. (Eds.), Turbulence and mixing in the ocean. Proceedings of the $19^{\text {th }}$ Liège Colloquium on Ocean Hydrodynamics. Amsterdam: Elsevier Oceanography Series 46, 387-404.

Pingree, R.D., 1993. Flow of surface waters to the west of the British Isles and in the Bay of Biscay. Deep-Sea Research 40, 369-388.

Pingree, R.D., 1994. Winter warming in the southern Bay of Biscay and Lagrangian eddy kinematics from a deep-drogued Argos buoy. Journal of the Marine Biological Association of the U.K. 74, 107-128.

Pingree, R.D., 1995. The droguing of Meddy Pinball and seeding with ALACE floats. Journal of the Marine Biological Association of the U.K. 75, 235-252. 
Pingree, R.D., Mardell., G.T., Holligan, P.M., Griffiths, D.K., Smithers, J. 1982. Celtic Sea and Armorican current structure and the vertical distributions of temperature and chlorophyll. Continental Shelf Research 1, 99-116.

Pingree, R.D., Griffiths, D.K., Mardell, G.T., 1983. The structure of the internal tide at the Celtic Sea shelf break. Journal of the Marine Biological Association of the UK. 64, 99-113.

Pingree, R.D., Griffiths, D.K., 1984. Trapped diurnal waves on Porcupine and Rockall Banks. Journal of the Marine Biological Association of the UK. 64, 889-897.

Pingree, R.D., New, A.L., 1989. Downward propagation of internal tidal energy into the Bay of Biscay. Deep-Sea Research 36, 735-758.

Pingree, R.D., Le Cann, B., 1989. Celtic and Armorican slope and shelf residual currents. Progress in Oceanography 23, 303-338.

Pingree, R.D., Le Cann, B., 1990. Structure, strength and seasonality of the slope currents in the Bay of Biscay region. Journal of the Marine Biological Association of the UK. 70, 857-885.

Pingree, R.D., Le Cann, B., 1992a. Three anticyclonic Slope Water Oceanic EDDIES (SWODDIES) in the Southern Bay of Biscay in 1990. Deep-Sea Research 39, 1147-1175.

Pingree, R.D., Le Cann, B., 1992b. Anticyclonic Eddy X91 in the Southern Bay of Biscay, May 1991 to February 1992. Journal of Geophysical Research 97, 14353-14367.

Pingree, R.D., New, A.L., 1995. Structure, seasonal development and sunglint spatial coherence of the internal tide on the Celtic and Armorican shelves and in the Bay of Biscay. Deep-Sea Research 42, 245-284.

Pingree, R.D., Sinha, B., Griffiths, C.R., 1999. Seasonality of the European slope current (Goban Spur) and ocean margin exchange. Continental Shelf Research, 19, 929-975.

PML, 1995. RRS "Charles Darwin" Cruise 97/95 Report, 12 October - 6 November. Plymouth Marine Laboratory, 84pp.

Pollard, R.T., Rhines, P.B., Thompson, R.O.R.Y., 1973. The deepening of the wind-mixed layer. Geophysical and Astrophysical Fluid Dynamics 3, 381-404.

Pollard, R.T., Griffiths, M.J., Cunningham, S.A., Read, J.F., Pérez, F.F., Ríos, A.F., 1996. Vivaldi 1991 - A study of the formation, circulation and ventilation of Eastern North Atlantic Central Water. Progress in Oceanography 37, 167-192.

Prandle, D., 1984. A modelling study of the mixing of ${ }^{137} \mathrm{Cs}$ in the seas of the European continental shelf. Philosophical Transactions of the Royal Society of London A310, 407-436.

Raine, R.,McMahon, T. 1998. Physical dynamics on the continental shelf off southwestern Ireland and their influence on coastal phytoplankton blooms. Continental Shelf Research, 18, 883-914.

Rees, A.P., Joint, I., Donald, K.M., 1999. Early spring bloom phytoplankton-nutrient dynamics at the Celtic Sea shelf edge. Deep-Sea Research I 46, 483-510.

Serpette, A., Mazé, R., 1989. Internal tides in the Bay of Biscay: a two-dimensional model. Continental Shelf Research 9, 795-821.

Shapiro, G.I., Hill, A.E., 1997. Dynamics of dense water cascades at the shelf edge. Journal of Physical Oceanography 27, 2381-2394.

Stigebrandt, A., Aure, J., 1989. Vertical mixing in basin waters of fjords. Journal of Physical Oceanography 19, 917-926.

Swallow, J.C., Gould, W.J., Saunders, P.M., 1977. Evidence for a poleward eastern boundary current in the North Atlantic Ocean. International Council for the Exploration of the Sea, C.M. 1977/C:32, Hydrography Committee, 11pp.

Taylor, J.R., 1993. Turbulence and mixing in the boundary layer generated by shoaling internal waves. Dynamics of Atmospheres and Oceans 19, 233-258.

Tett, P., Edwards, A., 1984. Mixing and plankton: an interdisciplinary theme in oceanography. Oceanography and Marine Biology. An Annual Review 22, 99-123. 
Thomsen, L., van Weering, T.C.E., 1998. Spatial and temporal variability of particulate matter in the benthic boundary layer at the North West European continental margin (Goban Spur). Progress in Oceanography 42, 61-76.

Thorpe, S.A., 1987a. On the reflection of a train of finite-amplitude internal waves from a uniform slope (with appendix by S.A. THORPE and A.P. HAINES) Journal of Fluid Mechanics 178, 279-302.

Thorpe, S.A., 1987b. Current and temperature variability on the continental slope. Philosophical Transactions of the Royal Society of London A323, 471-517.

Thorpe, S.A., 1992. The generation of internal waves by flow over the rough topography of a continental slope. Proceedings of the Royal Society of London A439, 115-130.

Thorpe, S.A., White, M., 1988. A deep intermediate nepheloid layer. Deep-Sea Research 35, $1665-1671$.

Thorpe, S.A., Hall, P., White, M., 1990. The variability of mixing at the continental slope. Philosophical Transactions of the Royal Society of London A331, 183-194.

Toole, J.M., Polzin, K.L., Schmitt, R.W., 1994. Estimates of diapycnal mixing in the abyssal ocean. Science 264, 1120-1123.

Tsuchiya, M.T., Talley, L.D., McCartney, M.S., 1992. An eastern Atlantic section from Iceland southward across the equator. Deep-Sea Research 39, 1885-1917.

van Aken, H.M., 2000. The hydrography of the mid-latitude northeast Atlantic Ocean: I, the deep water masses. Deep-Sea Research, in press.

van Aken, H.M., Becker, G., 1996. Hydrography and through-flow in the north-eastern North Atlantic Ocean: the NANSEN project. Progress in Oceanography 38, 297-346.

Vangriesheim, A., Khripounoff, A., 1990. Near-bottom particle concentration and flux: temporal variations observed with sediment traps and nepholometer on the Meriadzek Terrace, Bay of Biscay. Progress in Oceanography 24, 103-116.

Walsh, J.J., Biscaye, P.E., Csanady, G.T., 1988. The 1983-84 Shelf Edge Exchange Processes (SEEP) - I experiment: hypotheses and highlights. Continental Shelf Research 8, 435-456.

WAMDI Group, 1988. The WAM model - a third generation ocean wave prediction model. Journal of Physical Oceanography 18, 1775-1810.

Wang, X., 1992. Interaction of an eddy with a continental slope. Woods Hole Oceanographic Institution report WHOI-92-40.

White, M., Bowyer, P., 1997. The shelf-edge current north-west of Ireland. Annales Geophysicae 15, 1076-1083.

White, M., Raine, R., Bowyer, P., 1997. Slope current dynamics and variability west of Ireland. In: Ocean Margin Exchange OMEXII-I Final Report A, 65-96.

Whitehead, J.A., 1993. A laboratory model of cooling over the continental shelf. Journal of Physical Oceanography 23, 2412-2427. 


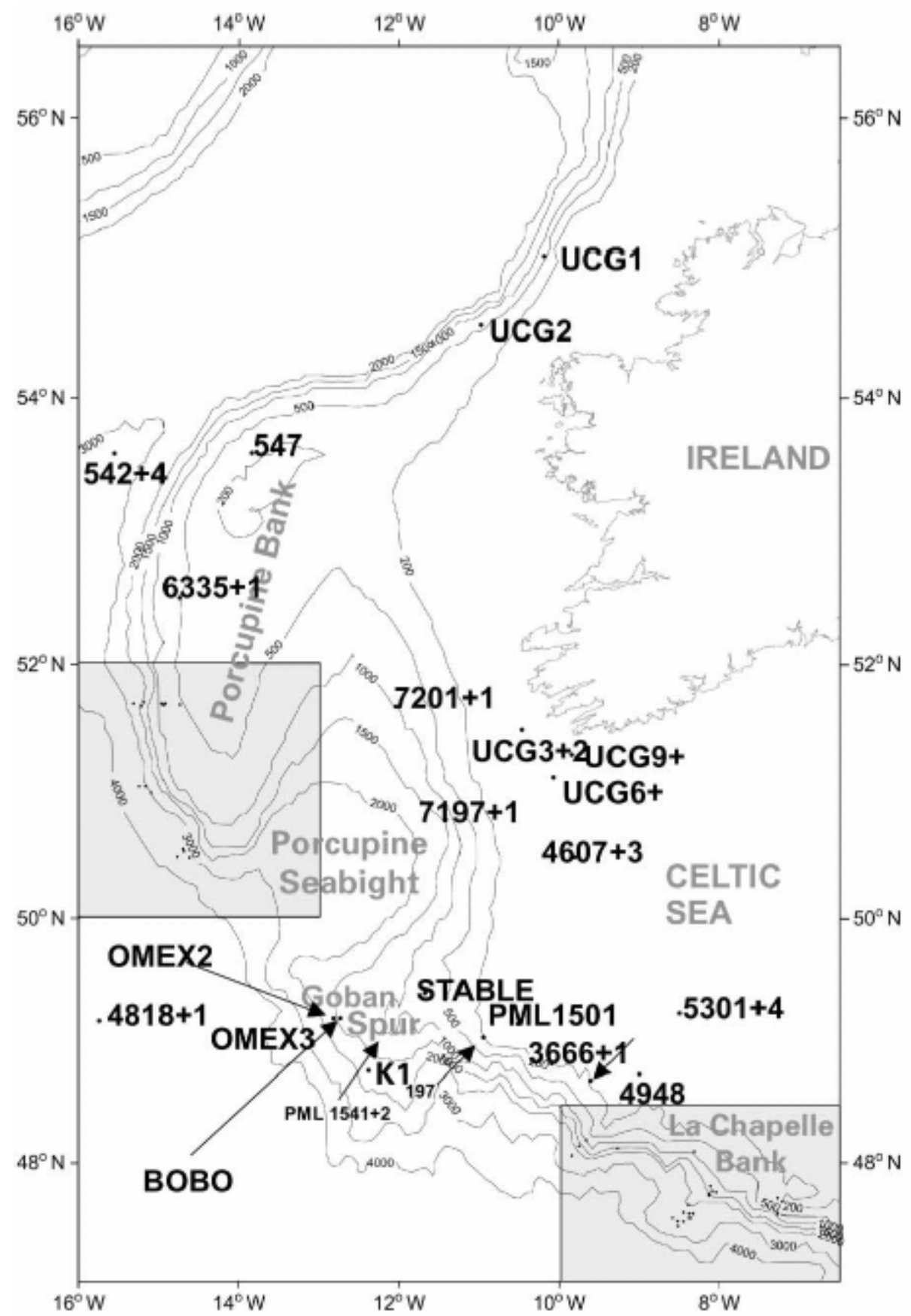

Fig. 1. Locations of moorings west and south of Ireland and used in the analyses (cf. Table 2), BOBO, STABLE and meteorological buoy K1. Areas of dense moorings SW of Porcupine Bank and La Chapelle Bank are shown expanded. 


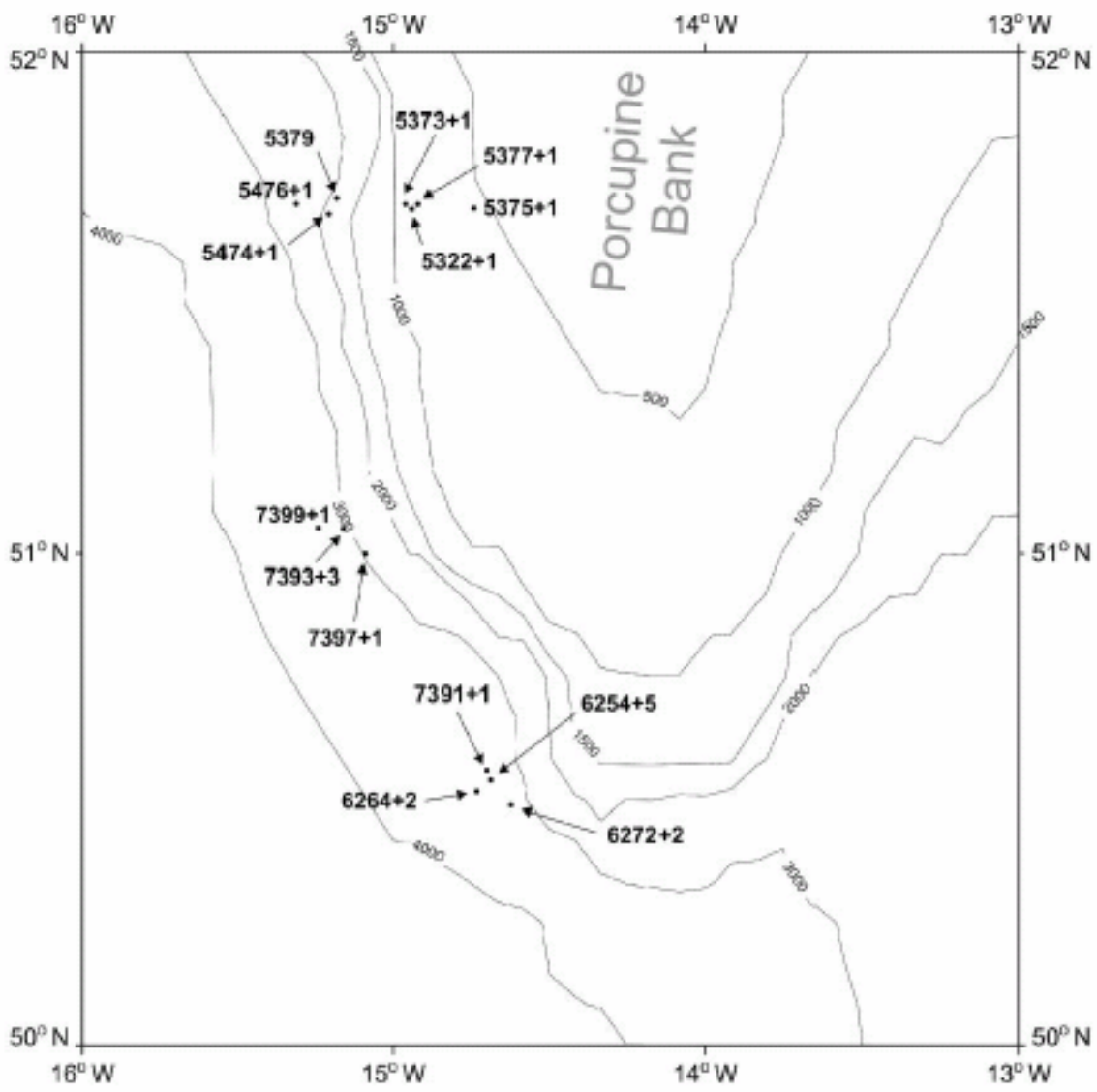

(b)

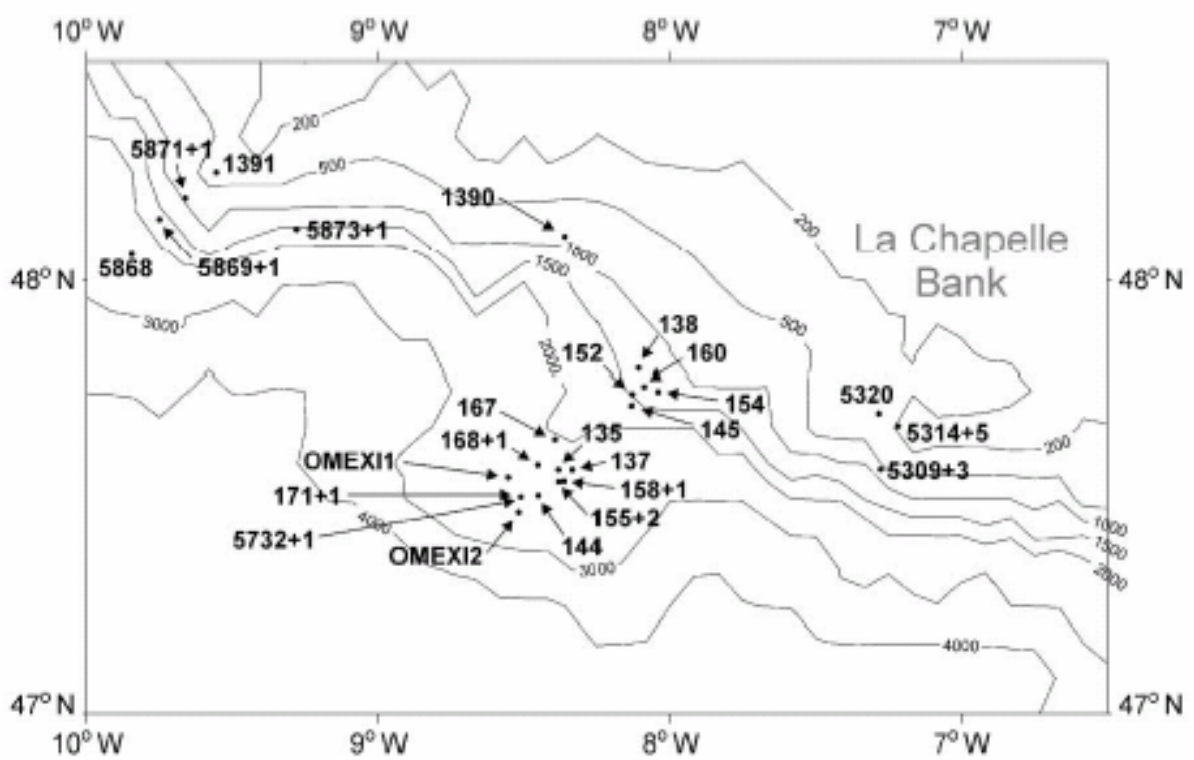

(c)

Fig. 1 (continued) 

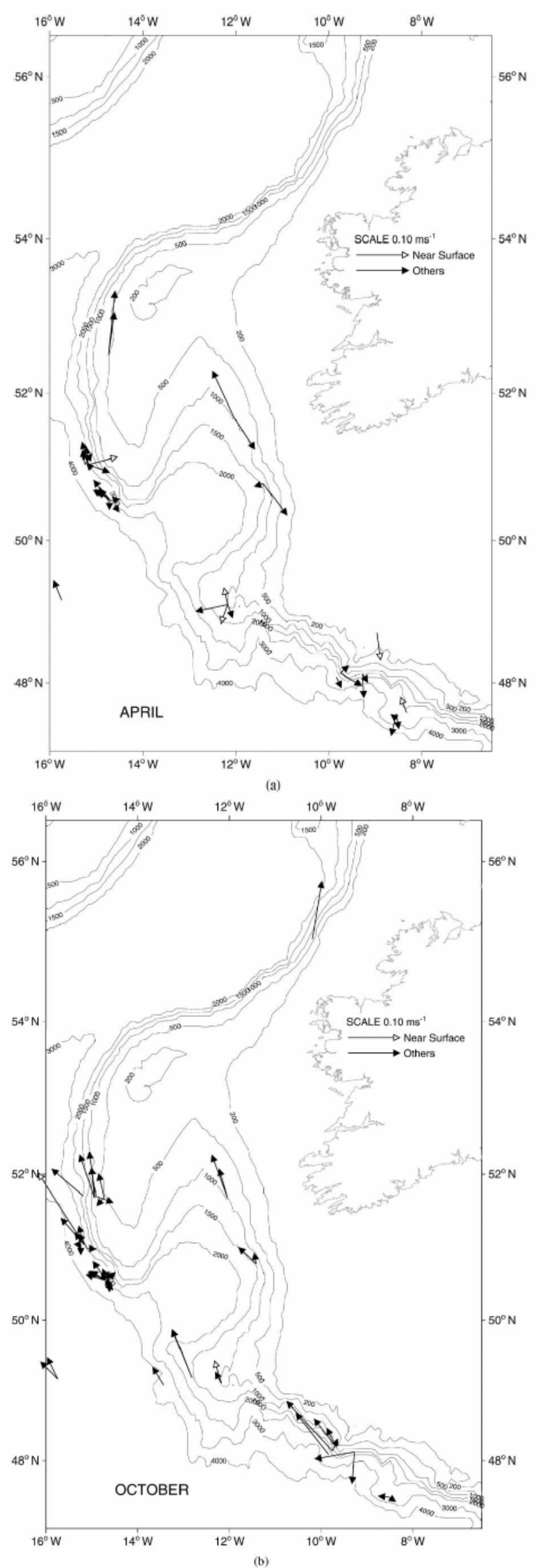

Fig. 2. October and April mean flows from current-meter records with at least 25 days in the month shown. 

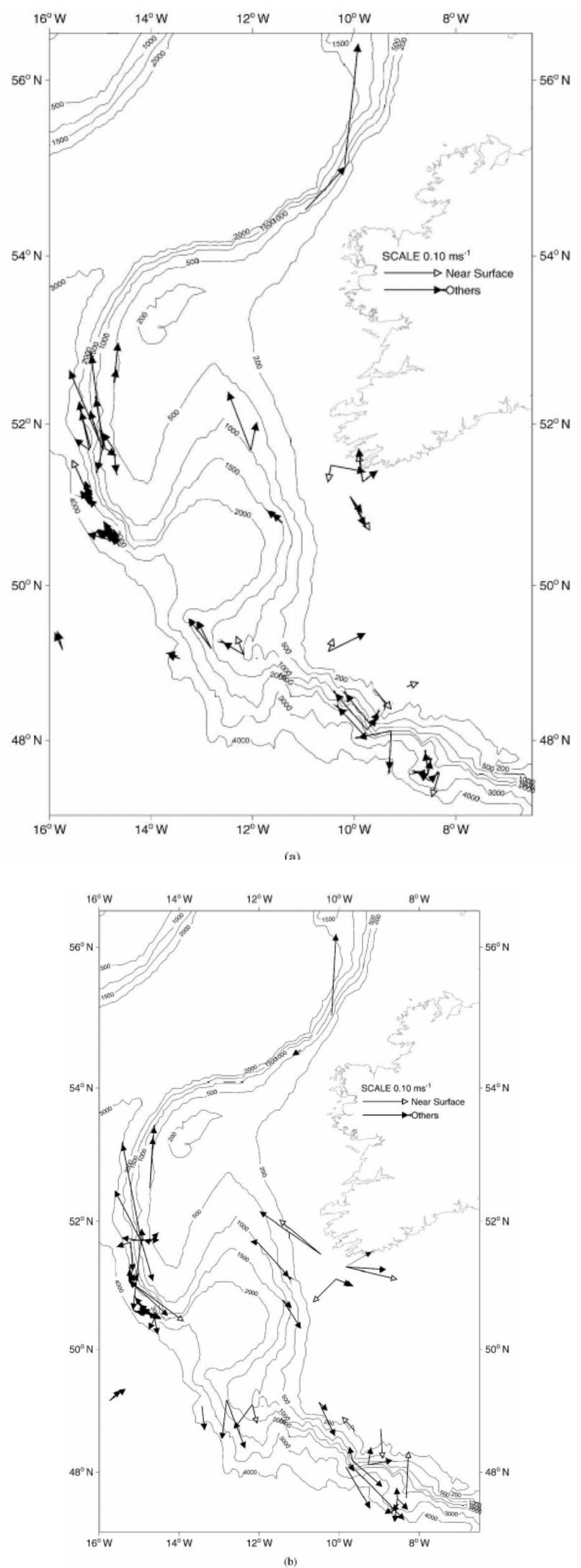

Fig. 3. Best-fit decomposition (2) to (a) mean and (b) seasonally varying flow contributions. The seasonally varying part (b) is multiplied by the monthly factor (c), always a reduction owing to the standard normalisation $\Sigma_{\mathrm{t}} \mathrm{c}^{2}$ $=1$. In (c), $\bullet-$ results from the complete analysis; + - results from analysis restricted to records of three months or more. 


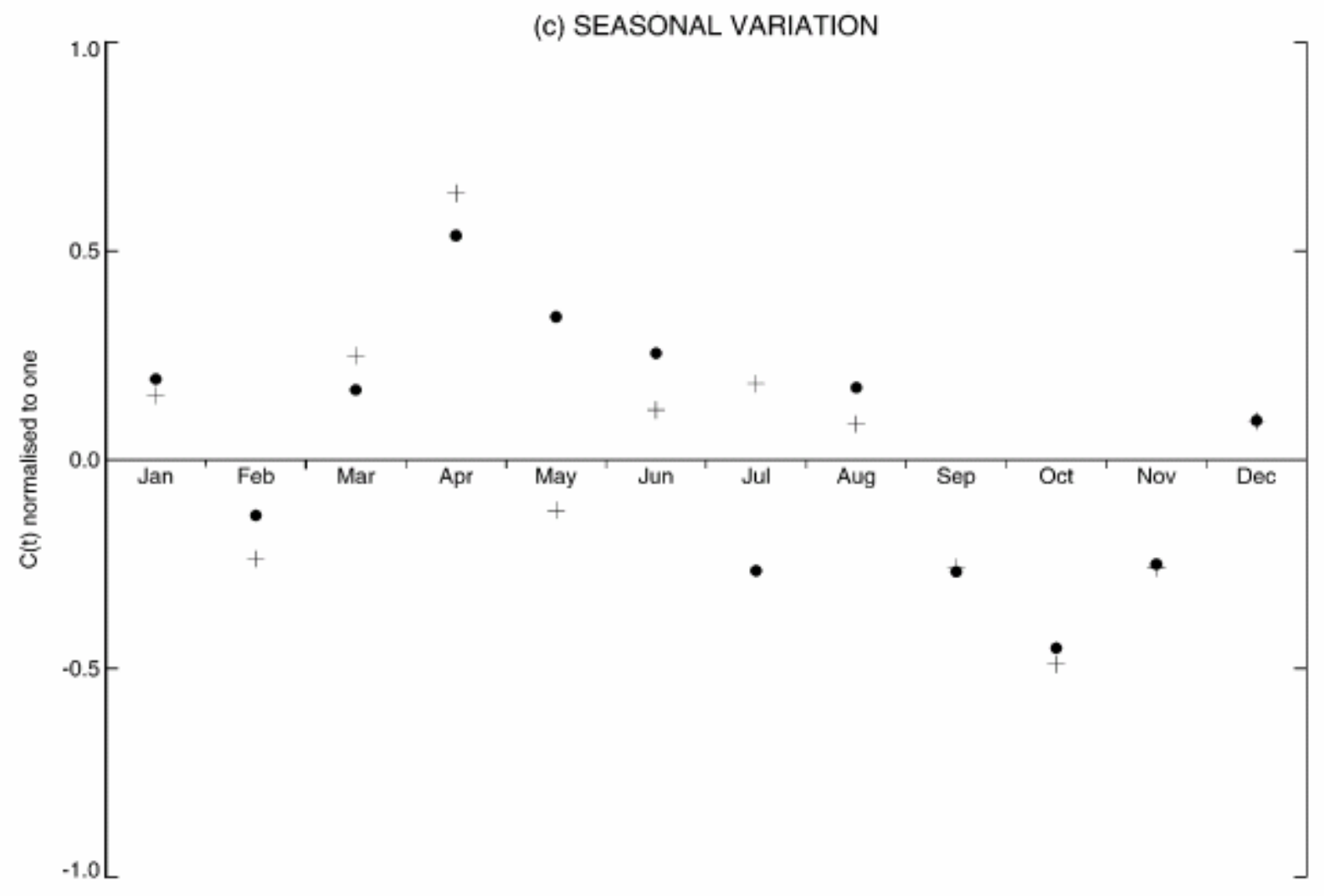

Fig. 3 (continued) 


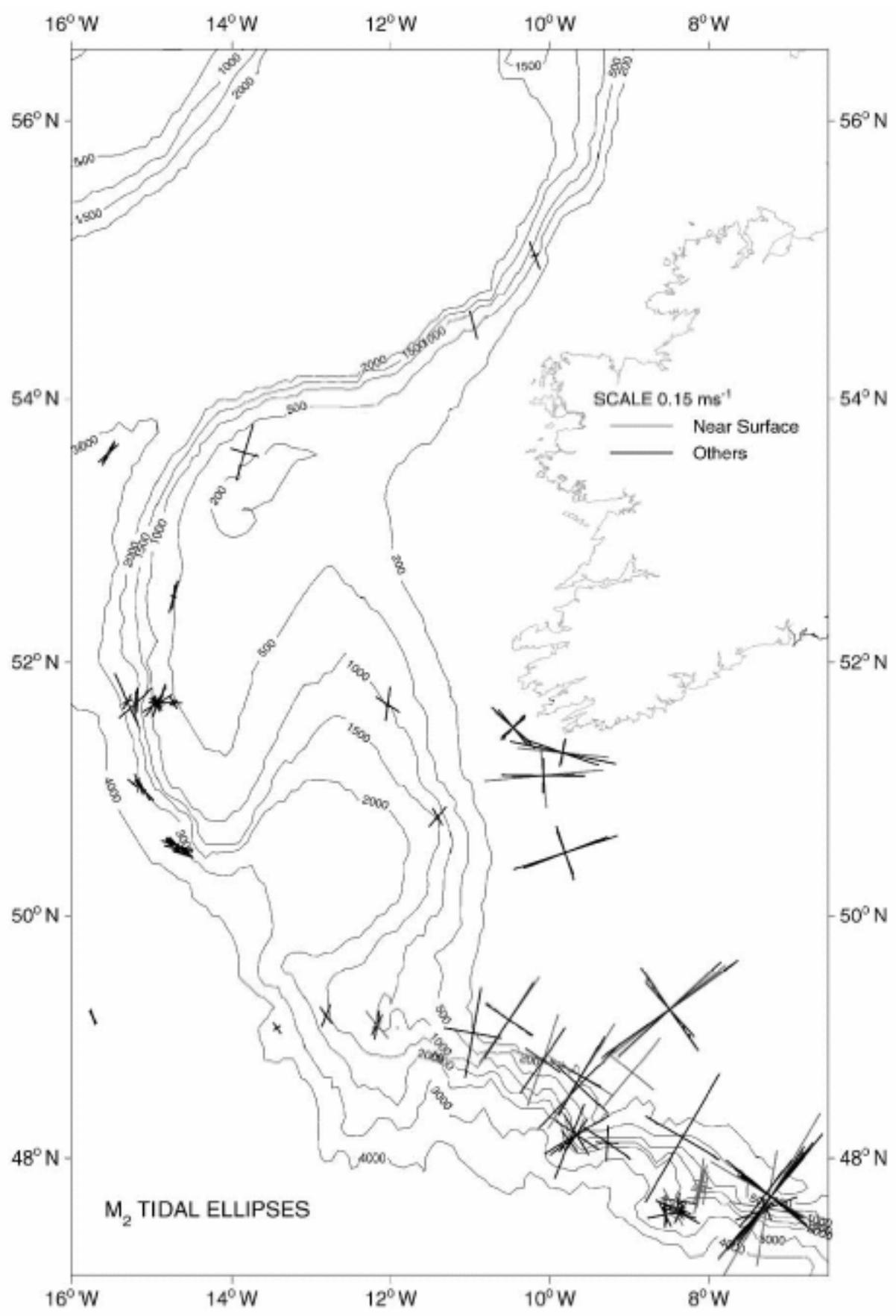

Fig. 4. $M_{2}$ tidal ellipses.

Fig. 4. $\mathrm{M}_{2}$ tidal ellipses. 


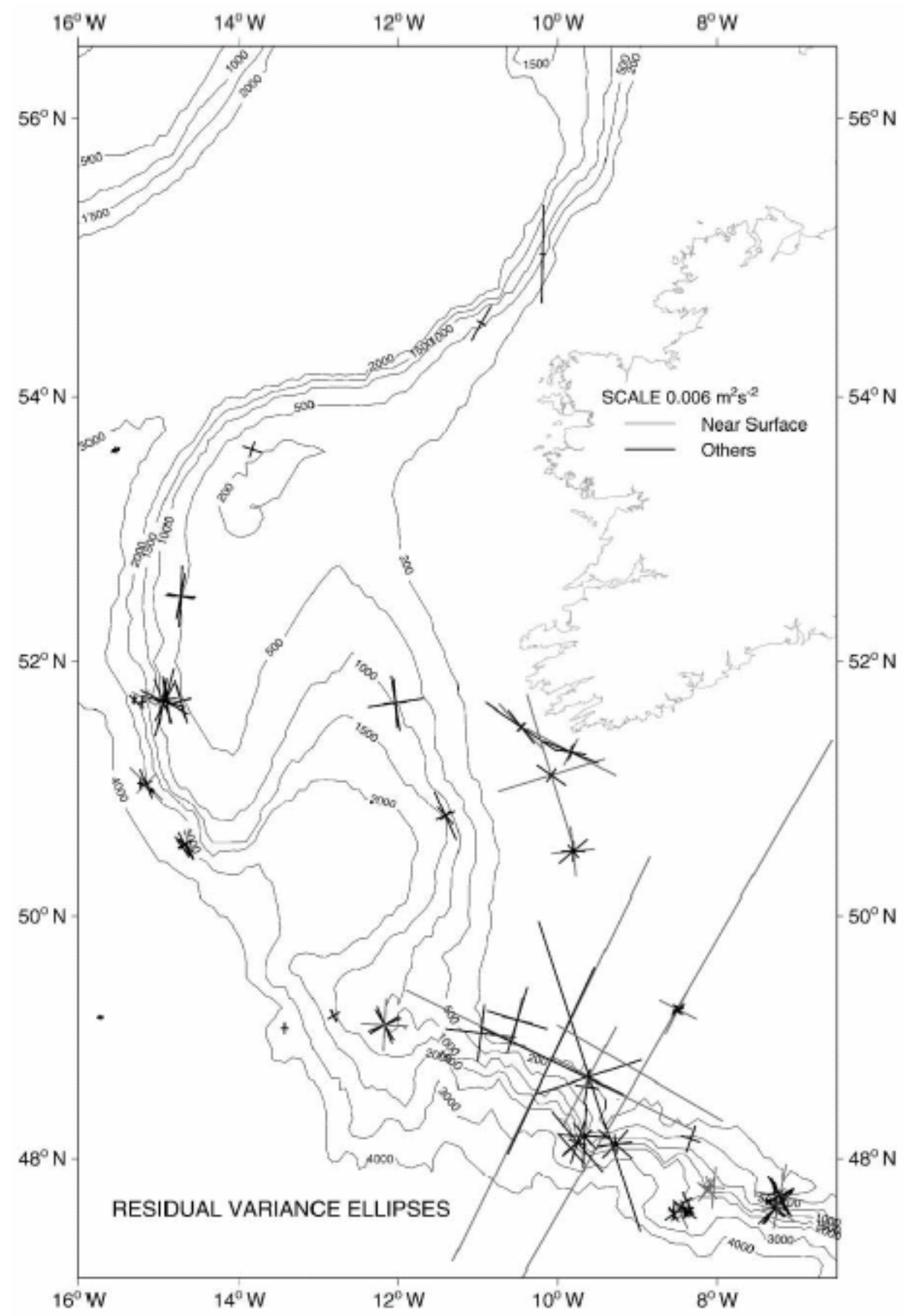

Fig. 5. Residual variance ellipses.

Fig. 5. Residual variance ellipses. 

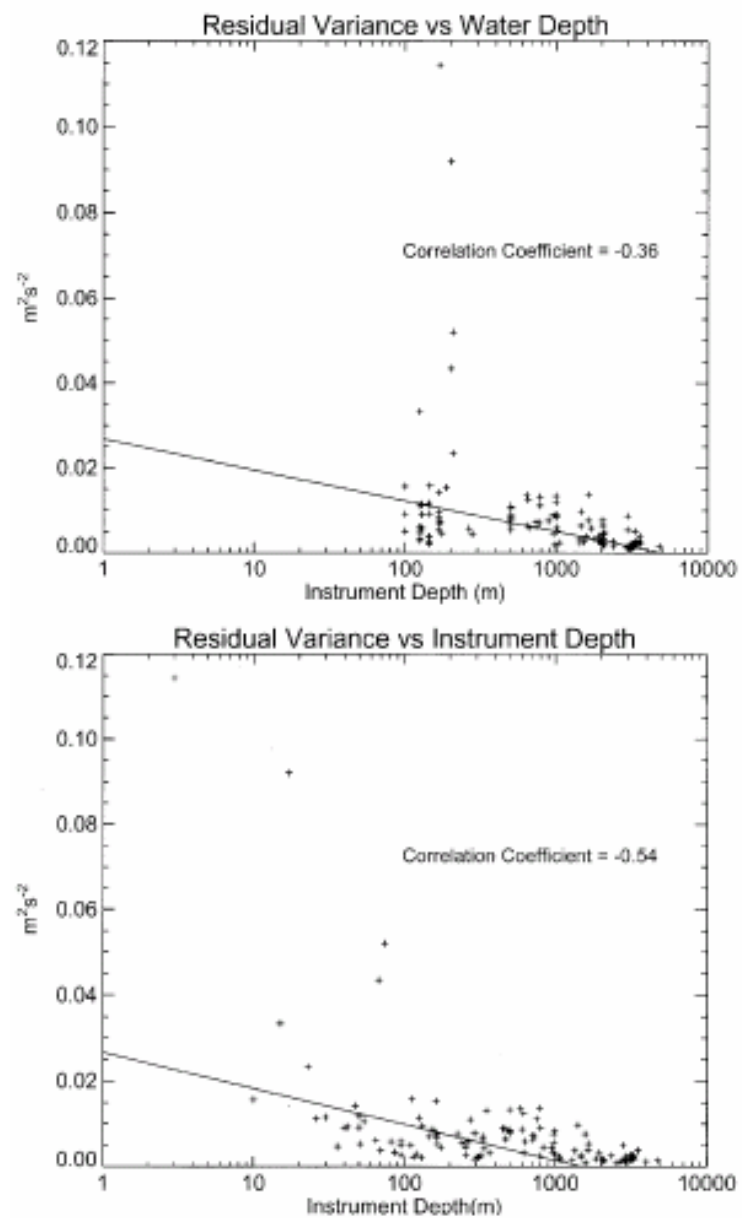

Fig. 6. Residual variance (major + minor axis of variance ellipse) plotted against water depth (top) and instrument depth (bottom).

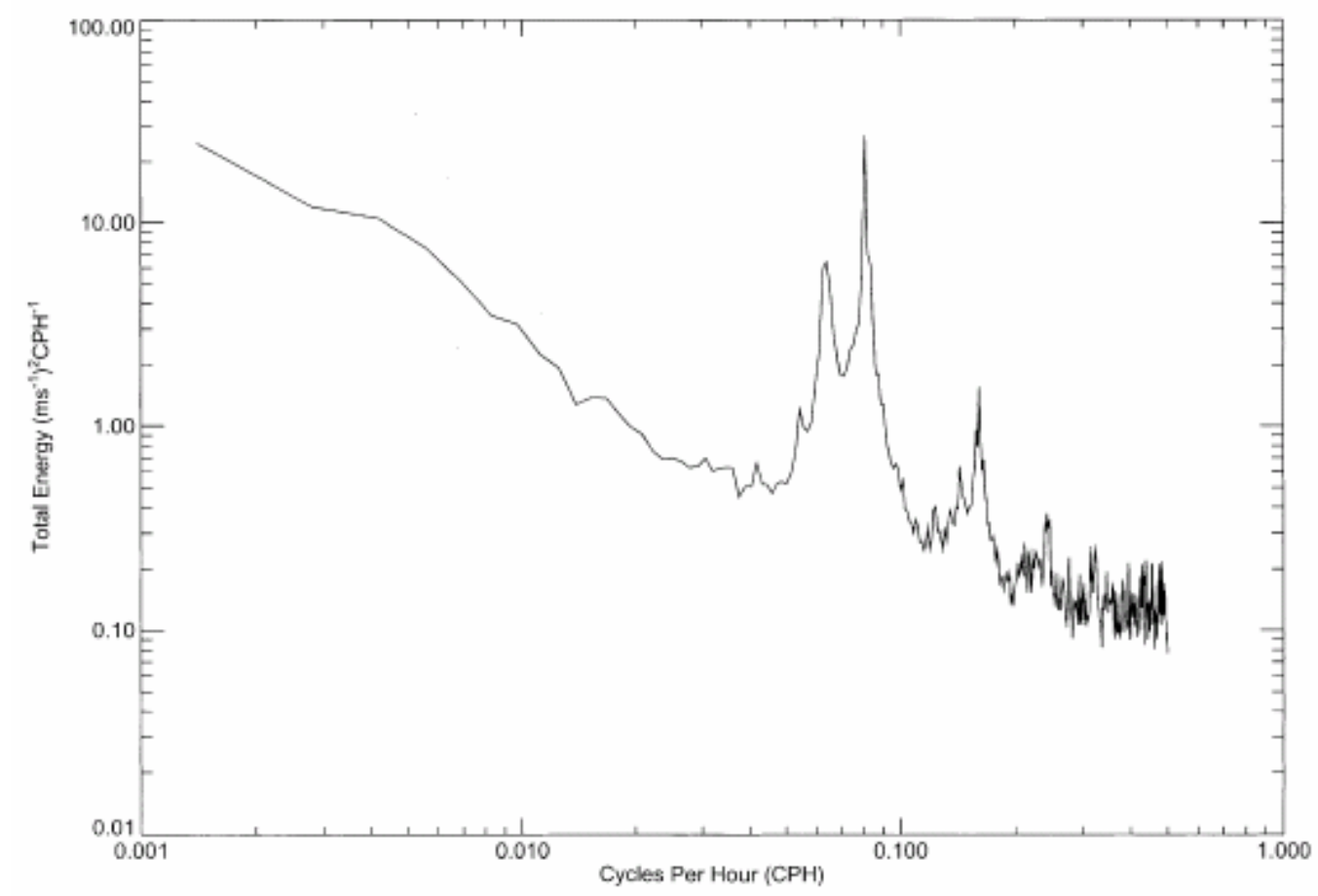

Fig. 7. Sum of spectral densities of series in Table 2, after tidal analysis removing coherent tides. The spectral analysis is on 30-day blocks for all series (hence plotted points are variance $\times 360$ ). 


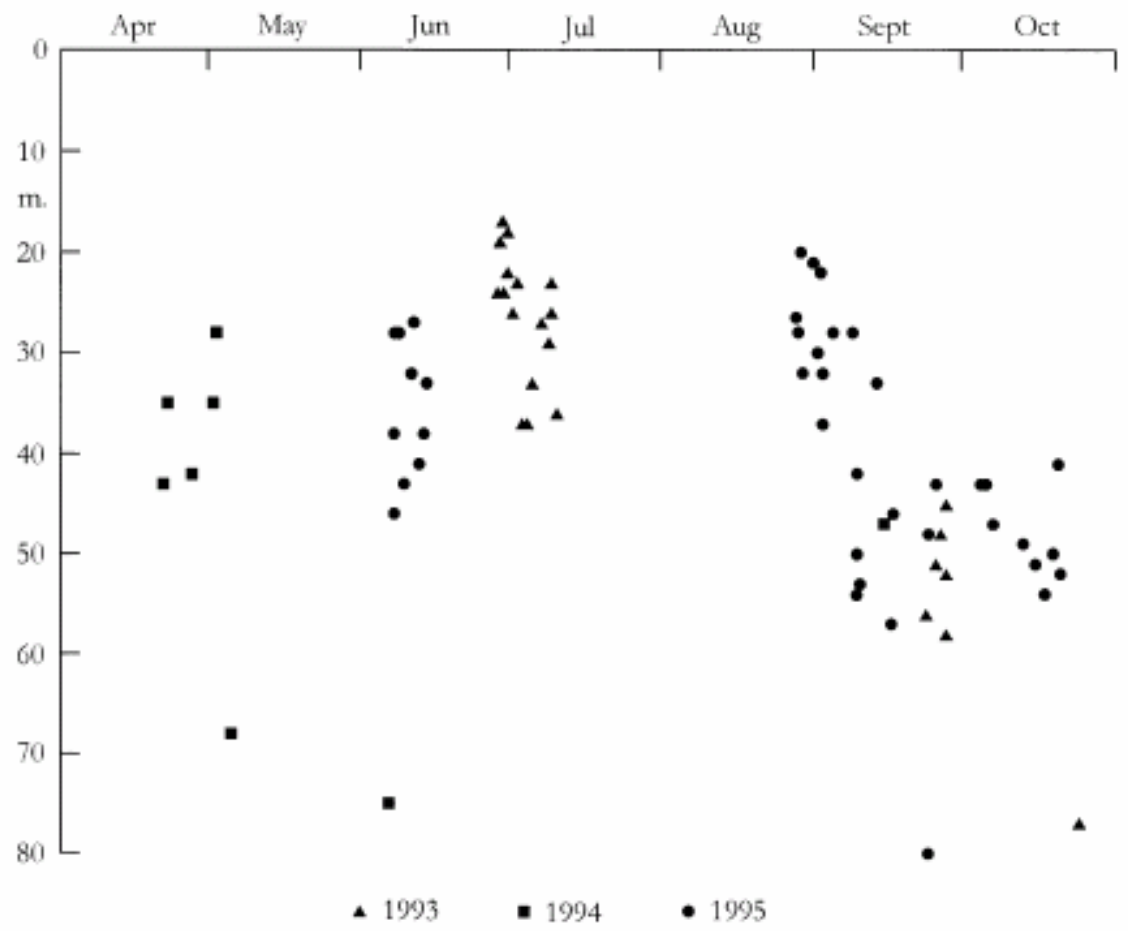

Fig. 8. Seasonal mixed layer depths estimated from "repeat" CTD profiles in 1993-1995.

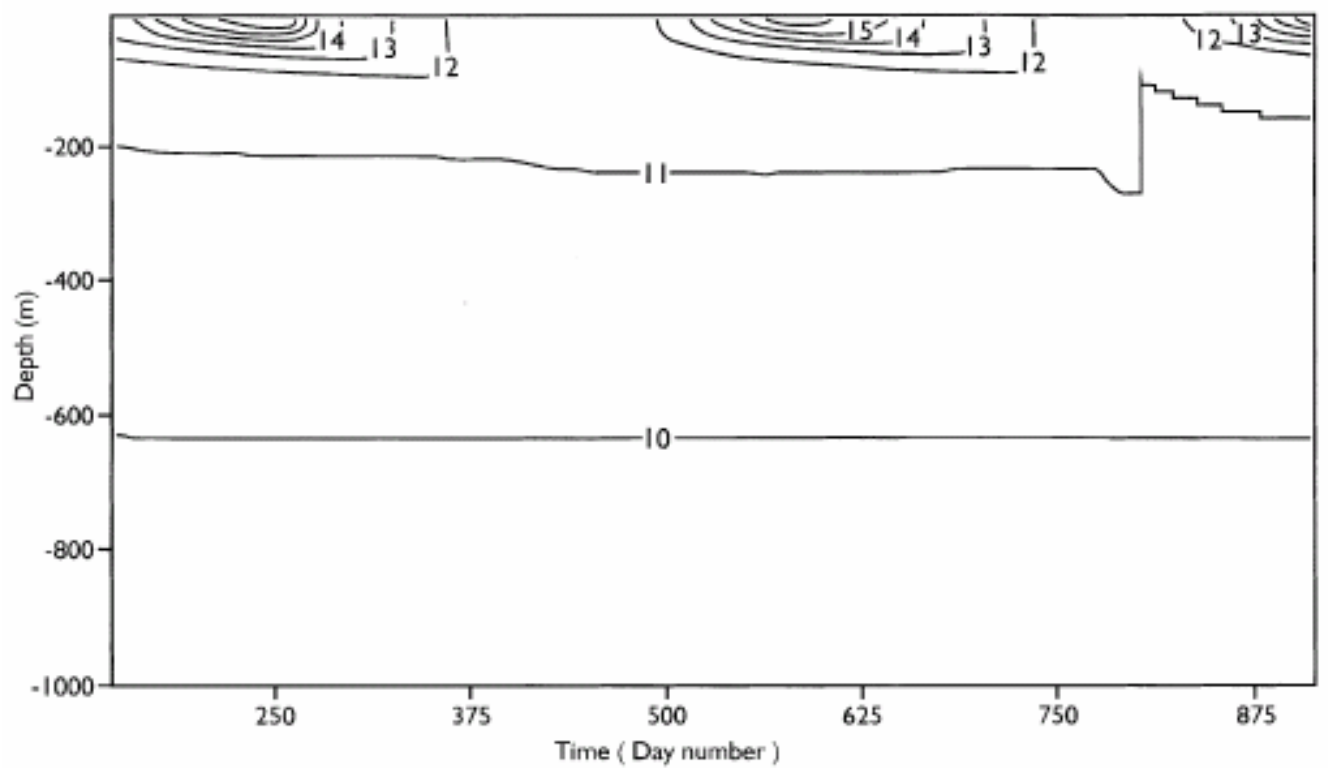

Fig. 9. Temperature dependence on depth and time (1 June 1993, i.e., day 152, to July 1995) with the turbulence kinetic energy model. (Day 1 is 1 January 1993). 

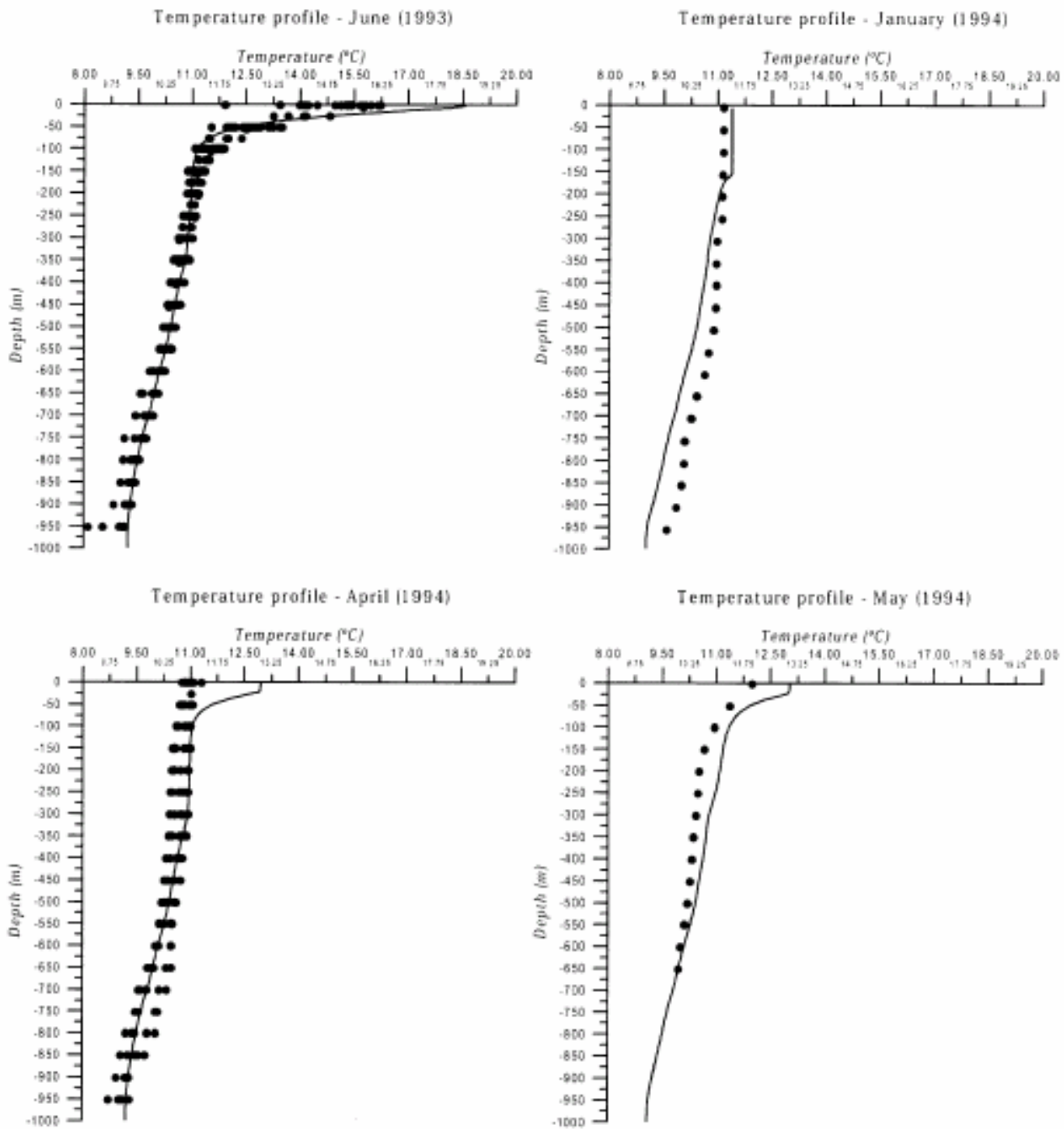

Temperature profile - June (1994)

Temperature profile - September (1994)
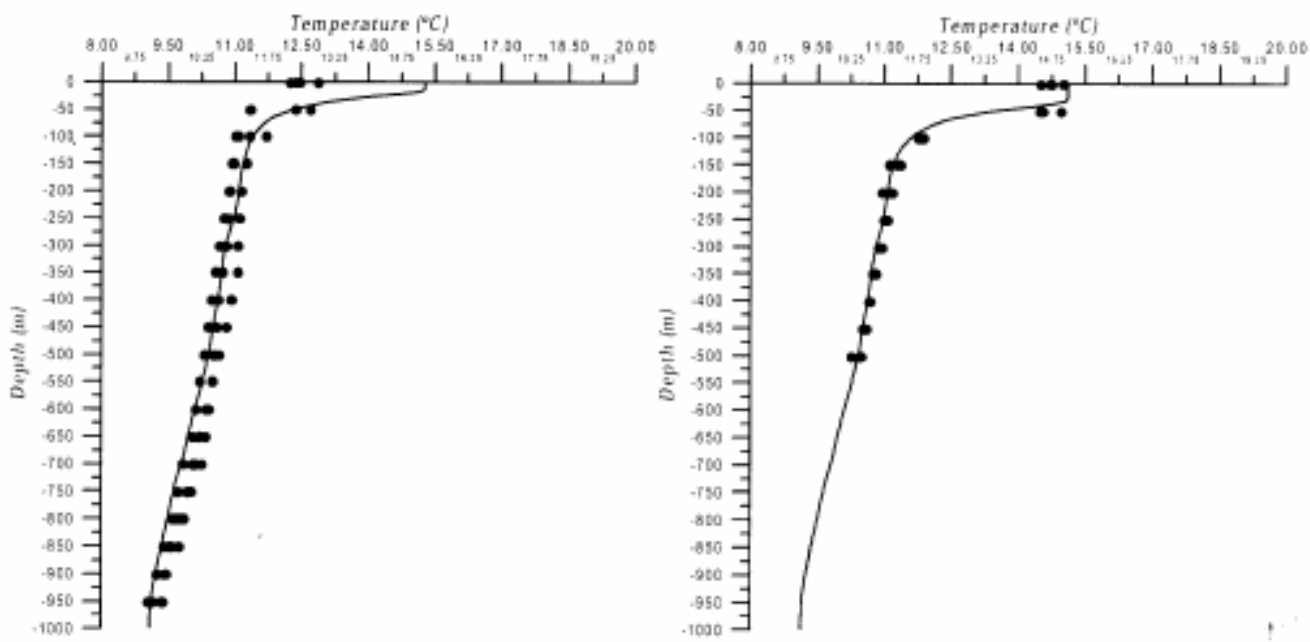

Fig. 10. Comparison of monthly mean temperature profiles obtained with the turbulence kinetic energy model (lines) and observed temperature profiles (dots) during OMEX I in the Goban Spur area. 


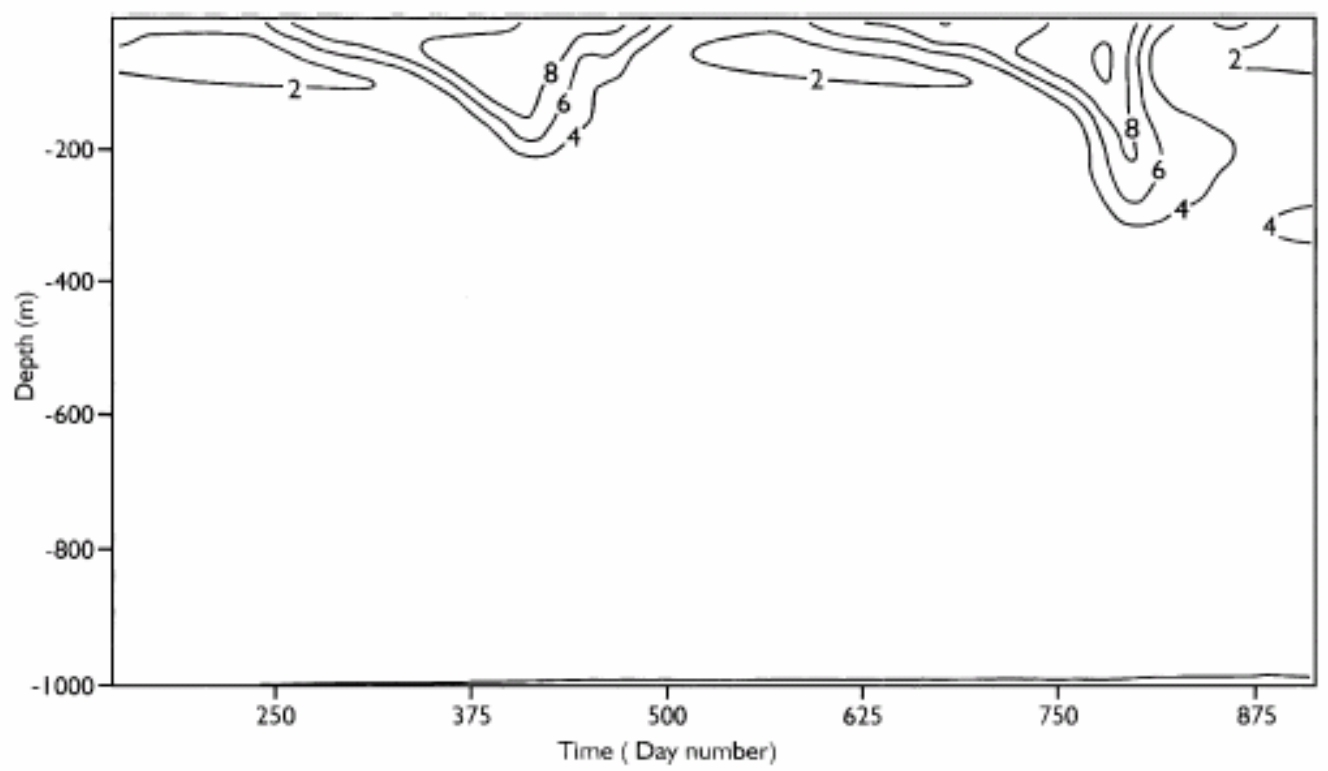

Fig. 11. Turbulence eddy diffusivity $\left(\mathrm{K}_{\mathrm{m}}\right)$ dependence on depth and time (June 1993 to July 1995) with the turbulence kinetic energy model. Isolines of $\log _{\mathrm{e}} 10^{5} \mathrm{~K}_{\mathrm{m}}$ for weekly mean values of $\mathrm{K}_{\mathrm{m}}$ in $\mathrm{m}^{2} \mathrm{~s}^{-1}$ are shown. (Day 1 is 1 January 1993). 
Table 1. Notation: other variables are defined locally

\begin{tabular}{|c|c|c|c|}
\hline Symbol & Meaning (source for value) & Value & Unit \\
\hline a & surface wave amplitude (Draper, 1991) & 1.2 & $\mathrm{~m}$ \\
\hline b & buoyancy $g\left(\rho_{0}-\rho\right) / \rho_{0}$ & 0.01 & $\mathrm{~m} \mathrm{~s}^{-2}$ \\
\hline$c(t)$ & normalised form of seasonal cycle & $\sum_{t} c^{2}=1$ & l \\
\hline$c_{k}$ & turbulence model: coefficient for momentum diffusivity & I & I \\
\hline $\mathrm{C}_{\varepsilon}$ & turbulence model: coefficient for dissipation & I & I \\
\hline$C_{D}$ & quadratic bottom friction coefficient & 0.003 & I \\
\hline $\mathrm{C}_{\mathrm{p}}$ & specific heat (for water) & 4200 & $\mathrm{~J} \mathrm{~kg}^{-1} \circ \mathrm{C}^{-1}$ \\
\hline$E$ & turbulence kinetic energy / $\rho$ & l & $m^{2} s^{-2}$ \\
\hline f & Coriolis parameter & 0.00011 & $s^{-1}$ \\
\hline $\mathrm{F}_{\mathrm{sol}}$ & solar irradiance absorbed at sea surface & 100 & $\mathrm{~W} \mathrm{~m}^{-2}$ \\
\hline $\mathrm{F}_{\text {nsol }}$ & $\begin{array}{l}\text { non-solar heat flux into sea surface } \\
\qquad \text { (latent + sensible + long-wave) }\end{array}$ & 100 & $\mathrm{~W} \mathrm{~m} \mathrm{~m}^{-2}$ \\
\hline $\mathrm{F}_{\mathrm{S}}$ & surface heat flux $F_{\text {sol }}+F_{\text {sol }}$ (winter cooling; ICES, 1962) & 100 & $\mathrm{~W} \mathrm{~m}^{-2}$ \\
\hline g & gravitational acceleration & 9.8 & $\mathrm{~m} \mathrm{~s}^{-2}$ \\
\hline$g^{\prime}$ & reduced gravity: $\quad g \times \Delta \rho$ across thermocline $/ \rho$ & 0.014 & $\mathrm{~m} \mathrm{~s}^{-2}$ \\
\hline $\mathrm{h}$ & water depth (shelf - upper slope) & 150 & $\mathrm{~m}$ \\
\hline $\mathrm{h}_{\mathrm{x}}$ & depth gradient across slope & 0.01 to 0.05 & I \\
\hline $\mathrm{h}_{\mathrm{O}}$ & depth of principal ocean circulation / thermocline & 1000 & $\mathrm{~m}$ \\
\hline $\mathrm{h}_{\mathrm{O}} / \Delta \mathrm{h}$ & $h_{0} /\left(h_{0}-h\right)$ & 1 & I \\
\hline $\mathrm{h}_{0}^{2}\left|\rho^{-1} \nabla \rho\right|$ & steric slope $\times \mathrm{h}_{\mathrm{O}}($ Arhan et al., 1994) & 0.00011 & $\mathrm{~m}$ \\
\hline$h^{\prime}$ & depth of seasonal thermocline & 30 & $\mathrm{~m}$ \\
\hline k & linear bottom friction coefficient $\left(=\mathrm{C}_{\mathrm{D}}|\mathbf{u}|\right)$ & 0.3 & $\mathrm{~mm} \mathrm{~s}^{-1}$ \\
\hline $\mathrm{K}_{\mathrm{H}}$ & lateral diffusivity (this paper) & 200 & $\mathrm{~m}^{2} \mathrm{~s}^{-1}$ \\
\hline $\mathrm{K}_{\mathrm{h}}, \mathrm{K}_{\mathrm{s}}, \mathrm{K}_{\mathrm{m}}$ & $\begin{array}{l}\text { vertical diffusivities for heat, salinity, momentum } \\
\text { (modelled numerically, this paper) }\end{array}$ & $10^{-5}$ to $10^{-1}$ & $\mathrm{~m}^{2} \mathrm{~s}^{-1}$ \\
\hline $\mathrm{L}$ & local feature scale & 10 & $\mathrm{~km}$ \\
\hline $\mathrm{L}_{\mathrm{s}}$ & shelf width & 200 & $\mathrm{~km}$ \\
\hline$L_{T}$ & topographic length scale (over steep slope) & 10 to 50 & $\mathrm{~km}$ \\
\hline m & mean current (in mean + seasonal analysis) & l & $\mathrm{m} \mathrm{s}^{-1}$ \\
\hline$M_{2}$ & principal lunar semi-diurnal tide & 1.932 & cycles $\mathrm{d}^{-1}$ \\
\hline $\mathrm{N}$ & $\begin{array}{l}\text { Others are } S_{2}, N_{2}, O_{1}, K_{1}, P_{1} 2.000,1.896,0.930,1.003,0.997 \\
\text { Brunt Väisälä frequency }\left[-g \rho^{-1} \partial \rho / \partial z\right]^{1 / 2}\end{array}$ & & cycles $\mathrm{d}^{-1}$ \\
\hline & (OMEX CTDs for most of water column) & 0.003 & $S^{-1}$ \\
\hline & $\left(\left(g^{\prime} / h\right)^{1 / 2}\right.$ for seasonal thermocline $)$ & 0.01 & $\mathrm{~s}^{-1}$ \\
\hline $\mathbf{s}$ & seasonal current amplitude (in seasonal analysis) & l & $\mathrm{m} \mathrm{s}^{-1}$ \\
\hline S & salinity & 35.5 & l \\
\hline $\mathrm{t}$ & time, duration of wind forcing & $10^{5}$ & s \\
\hline$t_{D}$ & time constant for tidal shear dispersion (Prandle, 1984) & $10^{3}$ & S \\
\hline $\mathrm{T}$ & temperature & 10 & ${ }^{\circ} \mathrm{C}$ \\
\hline $\mathrm{u}$ & cross-slope tidal and other currents (this paper) & 0.1 & $\mathrm{~m} \mathrm{~s}^{-1}$ \\
\hline$\hat{u}$ & scale for fluctuating (dispersive) cross-slope currents & 0.1 & $\mathrm{~m} \mathrm{~s}^{-1}$ \\
\hline $\mathbf{u}$ & vector velocity & 0.1 & $\mathrm{~m} \mathrm{~s}^{-1}$ \\
\hline $\mathbf{u}_{\mathrm{H}}$ & horizontal velocity vector (u, v) & 0.1 & $\mathrm{~m} \mathrm{~s}^{-1}$ \\
\hline $\mathrm{v}$ & along-slope current (this paper) & 0.1 & $\mathrm{~m} \mathrm{~s}^{-1}$ \\
\hline W & vertical component of velocity, positive upwards & I & $\mathrm{m} \mathrm{s}^{-1}$ \\
\hline W & wind speed (Borresen, 1987) & 10 & $\mathrm{~m} \mathrm{~s}^{-1}$ \\
\hline z & vertical coordinate, positive upwards & 100 & $\mathrm{~m}$ \\
\hline$\alpha$ & $\begin{array}{l}\text { thermal expansion coefficient } \\
\qquad\left(\text { e.g., Bryan and Cox, 1972; } 11^{\circ} \mathrm{C}\right)\end{array}$ & 0.0002 & $\left({ }^{\circ} \mathrm{C}\right)^{-1}$ \\
\hline$\alpha^{\prime}$ & frontal exchange coefficient (Pingree, 1979) & 0.0055 & I \\
\hline$\Delta \mathrm{h}_{\mathrm{I}}$ & small random topography (BODC) & 50 & $\mathrm{~m}$ \\
\hline & (canyons) & 1000 & m \\
\hline$\varepsilon$ & turbulent dissipation & l & $\mathrm{m}^{2} \mathrm{~s}^{-3}$ \\
\hline$\zeta$ & surface tide amplitude in shelf sea (DEn, 1989) & 1.6 & $\mathrm{~m}$ \\
\hline$<\zeta>$ & internal tide soliton amplitude & 10 & $\mathrm{~m}$ \\
\hline & (Celtic Sea; Pingree and New, 1995) & 30 & $\mathrm{~m}$ \\
\hline
\end{tabular}


combined length of internal solitons per tide

(Pingree and New, 1995)

$\rho \quad$ sea-water density

$\sigma \quad$ tidal frequency $\left(\mathrm{M}_{2}\right)$

$\sigma_{\mathrm{W}} \quad$ surface-wave frequency (Draper, 1991)

$\tau \quad$ wind stress (Borresen, 1987)

(C) eddy circulation

(e.g., Harvey and Glynn, 1985; Pingree, 1995)
<..> $\quad$ ensemble average (usually effected as a time average)

$2 \quad \mathrm{~km}$

$1027 \quad \mathrm{~kg} \mathrm{~m}^{-3}$

$0.000141 \mathrm{~s}^{-1}$

$0.8 \quad \mathrm{~s}^{-1}$

$0.2 \quad \mathrm{~N} \mathrm{~m}^{-2}$

ensemble average (usually effected as a time average)

$2 \times 10^{4} \quad \mathrm{~m}^{2} \mathrm{~s}^{-1}$

.. deviation of quantity from ensemble average 
Table 2

Locations of moorings used in analyses. OMEX moorings are PML 150n, PML 154n, UCG1, UCG2, and those so identified; also $B O B O$ and $S T A B L E$ (not analysed here). Sources are cited as papers where possible; otherwise the institution is given (in all these cases the data are via BODC or an author): UKOOA - UK Offshore Operators Association; IOS -(the former) Institute of Oceanographic Sciences; IFREMER - Institut Francais de Recherche pour l'Exploitation de la Mer (Brest); UCG-University College Galway

\begin{tabular}{|c|c|c|c|c|c|c|}
\hline Lat ${ }^{\circ} \dot{N}$ & Long ${ }^{\circ} \mathrm{E}$ & Water depth & Meter depth & Start date & Length (days) & Source \\
\hline 47.67 & -7.22 & 167 & $47,132,154,162,164,165$ & $24 / 09 / 1983$ & 30 & Heathershaw (1985) \\
\hline 47.70 & -7.28 & 175 & 174 & $24 / 09 / 1983$ & 30 & Heathershaw (1985) \\
\hline 47.57 & -7.28 & 504 & $54,254,498,501$ & $23 / 09 / 1983$ & 30 & Heathershaw (1985) \\
\hline 47.75 & -8.04 & 895 & 226 & $14 / 06 / 1971$ & 50 & Swallow et al. (1977) \\
\hline 47.76 & -8.09 & 979 & 293 & $13 / 08 / 1971$ & 32 & Swallow et al. (1977) \\
\hline 47.80 & -8.11 & 1062 & 305 & $6 / 06 / 1969$ & 40 & Swallow et al. (1977) \\
\hline 47.72 & -8.13 & 1024 & 110 & $4 / 02 / 1971$ & 56 & Swallow et al. (1977) \\
\hline 47.74 & -8.13 & 1007 & 82 & $2 / 04 / 1971$ & 31 & Swallow et al. (1977) \\
\hline 47.64 & -8.39 & 1589 & 1348 & $6 / 11 / 1972$ & 39 & Swallow et al. (1977) \\
\hline 47.57 & -8.38 & 1750 & 368 & $6 / 09 / 1968$ & 44 & Swallow et al. (1977) \\
\hline 47.57 & -8.33 & 1976 & 257 & $25 / 03 / 1969$ & 70 & Swallow et al. (1977) \\
\hline 47.58 & -8.45 & 1901 & 323,1651 & $6 / 11 / 1972$ & 38 & Swallow et al. (1977) \\
\hline 47.51 & -8.45 & 2040 & 469 & $13 / 12 / 1970$ & 50 & Swallow et al. (1977) \\
\hline 47.52 & -8.55 & 2091 & 839,1850 & $7 / 11 / 1972$ & 37 & Swallow et al. (1977) \\
\hline 47.54 & -8.38 & 2042 & $338,1001,2021$ & $18 / 06 / 1971$ & $60,41,60$ & Swallow et al. (1977) \\
\hline 47.54 & -8.36 & 2018 & 312,972 & $7 / 08 / 1971$ & 48 & Swallow et al. (1977) \\
\hline 47.55 & -8.55 & 2065 & 1953,2063 & $29 / 05 / 1984$ & 149 & Vangriesheim and Khripounoff (1990) \\
\hline 47.55 & -8.55 & 2100 & 1930,2100 & $10 \& 4 / 11 / 93$ & 268,279 & IFREMER (Vangriesheim) \\
\hline 47.47 & -8.52 & 2100 & 1960,2100 & $23 / 04 / 1994$ & 248,411 & IFREMER (Vangriesheim) \\
\hline 48.17 & -8.33 & 267 & 242 & $3 / 11 / 1974$ & 33 & Cartwright et al. (1980) \\
\hline 48.72 & -8.97 & 170 & 3 & $1 / 06 / 1979$ & 92 & UKOOA \\
\hline 48.68 & -9.61 & 208 & 23,74 & $7 / 06 / 1979$ & 75,60 & Pingree and Le Cann (1989) \\
\hline 48.60 & -9.63 & 171 & 146 & $3 / 11 / 1974$ & 34 & Cartwright et al. (1980) \\
\hline 48.19 & -9.66 & 640 & 330,590 & $25 / 06 / 1980$ & 288 & Dickson (1989) \\
\hline 48.12 & -9.28 & 1465 & 715,1415 & $25 / 06 / 1980$ & 346 & Dickson (1989) \\
\hline 48.14 & -9.75 & 1640 & 790,1590 & $25 / 06 / 1980$ & 345 & Dickson (1989) \\
\hline 48.06 & -9.84 & 2030 & 980 & $25 / 06 / 1980$ & 346 & Dickson (1989) \\
\hline 48.82 & -10.09 & 202 & 17,68 & $7 / 06 / 1979$ & 59,68 & Pingree and Le Cann (1989) \\
\hline 49.24 & -8.50 & 145 & $30,70,95,115,130$ & $23 / 09 / 1983$ & 30 & IOS Taunton (Heathershaw) \\
\hline 49.04 & -10.97 & 187 & 162 & $5 / 09 / 1975$ & 24 & Cartwright et al. (1980) \\
\hline
\end{tabular}




\begin{tabular}{|c|c|c|c|c|c|c|}
\hline 49.15 & -10.52 & 142 & 30,100 & $14 / 06 / 1995$ & 129,81 & Pingree et al. (1999) \\
\hline 49.11 & -12.18 & 996 & $196,496,946$ & $21 / 01 / 1994$ & 502 & Pingree et al. (1999) \\
\hline 49.19 & -12.82 & 1445 & 620,1070 & $27 / 06 / 1993$ & 195 & Antia et al. (2001) \\
\hline 49.08 & -13.43 & 3651 & 1490 & $26 / 06 / 1993$ & 195 & Antia et al. (2001) \\
\hline 49.17 & -15.74 & 4820 & 3990,4770 & $8 / 06 / 1979$ & 336,301 & Dickson et al. (1985) \\
\hline 50.50 & -9.81 & 126 & $26,36,51,86$ & $30 / 08 / 1980$ & 55 & Howarth (1990) \\
\hline 50.79 & -11.41 & 960 & 461,952 & $18 / 09 / 87$ & 298 & Pingree and Le Cann (1989) \\
\hline 50.56 & -14.69 & 3314 & $\begin{array}{l}2813,3224,3244,3264 \\
3284,3304\end{array}$ & $6 / 09 / 1984$ & $\begin{array}{l}242,244,244,244, \\
244,100\end{array}$ & Thorpe (1987b) \\
\hline 50.54 & -14.72 & 3567 & $3265,3286,3517$ & $7 / 09 / 1984$ & $218,243,243$ & Thorpe (1987b) \\
\hline 50.49 & -14.62 & 3434 & $2934,3134,3284$ & $7 / 09 / 1984$ & $243,141,115$ & Thorpe (1987b) \\
\hline 50.56 & -14.70 & 3342 & 3142,3312 & $12 / 07 / 1986$ & 344 & Dickson (1989) \\
\hline 51.00 & -15.09 & 2945 & 2745,2915 & $12 / 07 / 1986$ & 344 & Dickson (1989) \\
\hline 51.05 & -15.16 & 2978 & $601,1661,2881,2948$ & $12 / 07 / 1986$ & 344 & Dickson (1989) \\
\hline 51.05 & -15.24 & 3220 & 2897,3190 & $13 / 07 / 1986$ & 344 & Dickson (1989) \\
\hline 51.12 & -10.08 & 125 & $15,65,120$ & $18 / 05 / 1994$ & $76,86,86$ & Raine and McMahon (1998) \\
\hline 51.30 & -9.84 & 100 & $10,50,95$ & $16 / 05 / 1994$ & 90 & Raine and McMahon (1998) \\
\hline 51.50 & -10.46 & 130 & $40,95,125$ & $16,18,16 / 04 / 93$ & $120,42,120$ & Raine and McMahon (1998) \\
\hline 51.69 & -14.74 & 500 & 293,471 & $14 / 05 / 1983$ & 187,197 & Norris and MacDougall (1986) \\
\hline 51.70 & -14.92 & 741 & 271,712 & $15 / 05 / 1983$ & 199,195 & Norris and MacDougall (1986) \\
\hline 51.70 & -14.96 & 778 & 332,728 & $26 / 10 / 1982$ & 90 & Norris and MacDougall (1986) \\
\hline 51.69 & -14.94 & 786 & 352,757 & $25 / 09 / 1982$ & 204,202 & Norris and MacDougall (1986) \\
\hline 51.68 & -15.21 & 1537 & 789,1487 & $26 / 06 / 1982$ & 90 & Dickson and McCave (1986) \\
\hline 51.71 & -15.18 & 1709 & 979 & $15 / 05 / 1983$ & 171 & Dickson and McCave (1986) \\
\hline 51.70 & -15.31 & 2404 & 1299,2354 & $26 / 06 / 1982$ & 90 & Dickson and McCave (1986) \\
\hline 52.51 & -14.74 & 505 & 275,451 & $10 / 10 / 1981$ & 207,206 & Norris and MacDougall (1986) \\
\hline 53.60 & -13.84 & 280 & 255 & $7 / 09 / 1975$ & 33 & Cartwright et al. (1980) \\
\hline 53.60 & -15.55 & 3118 & $1087,1594,2104,2550,2858$ & $8 / 09 / 1975$ & $31,30,31,31,31$ & Cartwright et al. (1980) \\
\hline 54.54 & -10.97 & 667 & 628 & $14 / 04 / 1994$ & 184 & White and Bowyer (1997) \\
\hline 55.04 & -10.19 & 655 & 615 & $15 / 04 / 1994$ & 233 & White and Bowyer (1997) \\
\hline
\end{tabular}


Table 3. Contributions to shelf-edge circulation: $\mathrm{m} \mathrm{s}^{-1}$

\begin{tabular}{lll}
\hline Process & Scale & Goban Spur \\
\hline coastal current & $?$ & $(0.1)$ \\
slope current & & 0.05 (typical observed) \\
forced by: JEBAR (Huthnance, 1984) & $\mathrm{h}_{\circ}{ }^{2}\left|\rho^{-1} \nabla \rho\right| \mathrm{g} / 8 \mathrm{k}$ & 0.45 \\
$\begin{array}{l}\text { steady wind (e.g., Huthnance, 1984) } \\
\text { unsteady wind (e.g., Huthnance, 1995) }\end{array}$ & $\tau / \rho \mathrm{k}$ & $0.32(\tau=0.1)$ \\
biased form drag (Huthnance, 1995; & $\mathrm{t} \tau / \rho \mathrm{h}$ & 0.13 (top $150 \mathrm{~m}, \tau=0.2)$ \\
$\begin{array}{l}\text { Haidvogel and Brink, 1986) } \\
\text { wave rectification (Huthnance, 1984; }\end{array}$ & $(\tau / 2 \pi \rho) \min (1 / \mathrm{k}, \mathrm{t} / \mathrm{h})$ & 0.02 \\
$\begin{array}{l}\text { Denbo and Allen, 1983) } \\
\text { eddy momentum (Garrett, 1979) }\end{array}$ & $\mathrm{u}^{2} \mathrm{f} / \mathrm{L}_{\top} \sigma^{2}$ & $<0.006$ \\
$\begin{array}{l}\text { eddies, jets } \\
\text { tides (Huthnance, 1995) }\end{array}$ & $? \mathrm{uvh}_{T} \mathrm{k}$ & $<0.1\left(\mathrm{~L}_{T}=50 \mathrm{~km}\right)$ \\
& $\zeta \max \left\{(\mathrm{g} / \mathrm{h})^{1 / 2}, \sigma \mathrm{L}_{\mathrm{S}} / \mathrm{h}\right\}$ & $\begin{array}{l}<0.1 \\
\text { actual } 0.1\end{array}$ \\
& & $\begin{array}{l}\text { actual }(0.2 \text { on shelf) } \\
\text { (estimate } 0.75 \text { Celtic Sea) }\end{array}$ \\
\hline
\end{tabular}

Table 4. Contributions to shelf-edge exchange: $\mathrm{m}^{2} \mathrm{~s}^{-1}$

\begin{tabular}{|c|c|c|}
\hline Process & Scale & Goban Spur \\
\hline slope current (Huthnance 1984, 1995) & $\mathrm{kv} / \mathrm{f}$ & $0.3(v=0.1)$ \\
\hline topographic irregularities (Holloway, 1987) & $\mathrm{v} \Delta \mathrm{h}_{\mathrm{l}}$ & 5 (locally only) \\
\hline eddy (Wang, 1992) & $C \mathrm{~h}_{\mathrm{O}}\left(\mathrm{h}_{\mathrm{O}} / \Delta \mathrm{h}\right) / \mathrm{f}$ & 2.1 Sv-days $\left(h_{0} / \Delta h=1\right)$ \\
\hline impulsive wind (e.g., Huthnance, 1995) & $\tau / \rho f$ & $1.8(\tau=0.2)$ \\
\hline upwelling - wind (e.g., Huthnance, 1995) & $\tau / \rho f$ & $0.9(\tau=0.1)$ \\
\hline cascading (Whitehead, 1993) & $\left(g \alpha / \rho C_{p}\right)^{2 / 3} h\left(F_{s}^{2} / L_{s}\right)^{1 / 3} /(0.6 f)$ & 0.8 \\
\hline front (Pingree, 1979) & $\alpha^{\prime} h\left(g^{\prime} h^{\prime}\right)^{1 / 2}$ & 0.5 \\
\hline tides (wide shelf; Huthnance, 1995) & $\sigma \zeta L_{s}$ & $\begin{array}{l}\text { actual } 30 \\
\text { (estimate } 113 \text { Celtic Sea) }\end{array}$ \\
\hline shear dispersion (Prandle, 1984) & $t_{D} u h|\mathbf{u}| / L_{T}$ & $\begin{array}{l}0.06\left(\mathrm{~L}_{T}=50 \mathrm{~km}\right. \\
\left.\mathrm{hu}=30=\sigma \zeta \mathrm{L}_{S}\right)\end{array}$ \\
\hline internal tide solitons (see Huthnance, 1995) & $<\zeta>\lambda /$ tide & $\begin{array}{l}0.4 ? \\
\text { ( } 1.3 \text { Celtic Sea) }\end{array}$ \\
\hline waves' Stokes drift (Kenyon, 1969) & $0.01 \mathrm{~W}^{2}$ & 1 \\
\hline slope current and bend $\theta$ in slope (Huthnance, 1987) & $v \theta k L_{T} / f$ & $<0.014 \theta \mathrm{Sv}$ \\
\hline ridge-associated upwelling (Killworth, 1978) & $\left(2 \Delta \mathrm{h} / \mathrm{h}_{\mathrm{O}}\right) \tau / \rho \mathrm{f}$ & 1.8 (locally) \\
\hline
\end{tabular}


Table 5. Contributions to energy potentially available for mixing: milliwatts $\mathrm{m}^{-2}$

\begin{tabular}{|c|c|c|}
\hline Process & Scale & Goban Spur \\
\hline $\begin{array}{c}\text { surface waves (WAMDI Group, 1988; } \\
\text { Huthnance 1995) } \\
\text { or (Melville, 1994) }\end{array}$ & $\begin{array}{l}1.5 \times 10^{-5} \rho g \sigma_{w} a^{2} \\
5 \times 10^{-7} \rho W^{3}\end{array}$ & $\begin{array}{l}174 \\
500\end{array}$ \\
\hline wind & $\tau \mathrm{V}$ & $20(\tau=0.2, v=0.1)$ \\
\hline $\begin{array}{l}\text { large internal tides (see Huthnance, 1995) } \\
\text { internal waves }{ }^{1} \text { (Huthnance, 1981) }\end{array}$ & $\begin{array}{l}\rho g^{\prime}<\zeta^{2}>\lambda / L_{T} \text { per tide } \\
0.1 \times 1 \text { kilowatts- } m^{-1} / L_{T}\end{array}$ & $\begin{array}{l}60 ? \\
10\end{array}$ \\
\hline $\begin{array}{l}\text { (Garrett and Gilbert, 1988) } \\
\text { canyon-intensified } \\
\text { bottom friction }\end{array}$ & $\begin{array}{l}\text { fn }\left(h_{x}, f / N\right) \times 30 \text { milliwatts } m^{-2} \text { flux } \downarrow \\
<\rho C_{D} u^{3}> \\
\rho C_{D} v^{3}\end{array}$ & $\begin{array}{l}0.1 \text { to } 1 \\
-(\sim 150, \text { Celtic Sea })\end{array}$ \\
\hline
\end{tabular}

Note: 1) The total energy from internal waves potentially available for mixing may be estimated as $\mathrm{O}(10$ milliwatts $\left.\mathrm{m}^{-2}\right)$ on the basis of a flux $\mathrm{O}\left(1\right.$ kilowatt $\mathrm{m}^{-1}$ ) from the ocean (Huthnance, 1981) that is "lost" across the slope, width $\mathrm{O}(100 \mathrm{~km})$; Holt and Thorpe (1997) estimate that the on-shelf flux is reduced to 0.16 watts $\mathrm{m}^{-2}$ in 200-m water depth at the Celtic Sea shelf edge south-east of Goban Spur. 